\title{
Article
}

\section{The Two Western Cultures of Privacy: Dignity Versus Liberty}

\author{
James Q. Whitman ${ }^{\dagger}$
}

CONTENTS

I. A Transatlantic Clash.

II. Dignity VERSUS LiBERTY. 1160

III. THE EUROPEAN TRADITION OF DIGNITY: LEVELING UP 1164

IV. THE RISE OF FRENCH PRIVACY LAW 1171

V. THE RISE OF GERMAN PRIVACY LAW

VI. CONTEMPORARY CONTINENTAL LAW: PROTECTING THE AVERAGE PERSON's PUBLIC IMAGE

VII. CONTEMPORARY CONTINENTAL LAW: FREE EXPRESSION AND PUBLIC NUDITY

$\uparrow$ Ford Foundation Professor of Comparative and Foreign Law, Yale University. Earlier versions of this paper were presented to the helpful audiences at the Unidem Seminar on European and American Constitutionalism, the Institut des Hautes Études sur la Justice, the FrenchAmerican Foundation of Paris, and Columbia and Yale Law Schools. The author would also like to thank Anita Allen, Friedrich Wenzel Bulst, Agnès Dunogué, Edward Eberle, William Edmundson, Christoph Paulus, and Jeffrey Rosen for their aid and advice. Unless otherwise noted, all translations are my own. 
VIII. WARREN AND BRANDEIS REVISITED ...................................... 1202

IX. The american Tradition: Protecting the Sanctity OF THE HOME

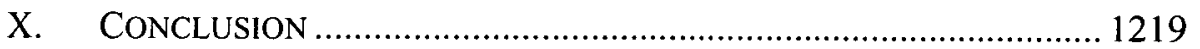




\section{A TRANSATLANTIC Clash}

In every corner of the Western world, writers proclaim "privacy" as a supremely important human good, as a value somehow at the core of what makes life worth living. Without our privacy, we lose "our very integrity as persons," Charles Fried declared over thirty-five years ago. 'Many others have since agreed that privacy is somehow fundamental to our "personhood." It is a commonplace, moreover, that our privacy is peculiarly menaced by the evolution of modern society, with its burgeoning technologies of surveillance and inquiry. Commentators paint this menace in very dark colors: Invasions of our privacy are said to portend a society of "horror,", to "injure [us] in [our] very humanity,"4 or even to threaten "totalitarianism," and the establishment of law protecting privacy is accordingly declared to be a matter of fundamental rights. ${ }^{6}$ It is the rare privacy advocate who resists citing Orwell when describing these dangers.

At the same time, honest advocates of privacy protections are forced to admit that the concept of privacy is embarrassingly difficult to define. ${ }^{7}$ "[N]obody," writes Judith Jarvis Thomson dryly, "seems to have any very clear idea what [it] is." Not every author is as skeptical as Thomson, but many of them feel obliged to concede that privacy, fundamentally important though it may be, is an unusually slippery concept. In particular, the sense of what must be kept "private," of what must be hidden before the eyes of others, seems to differ strangely from society to society. This is a point that is frequently made by citing the literature of ethnography, which tells us that there are some societies in which people cheerfully defecate in full view of others, and at least a few in which the same is true of having

1. Charles Fried, Privacy, 77 YALE L.J. 475, 477 (1968).

2. See, e.g., Jeffrey H. Reiman, Privacy, Intimacy, and Personhood, in PHILOsoPHICAL DimENSIONS OF PRIVACY: AN ANTHOLOGY 300, 310 (Ferdinand David Schoeman ed., 1984). For a more recent example of this widespread idea, see Jonathan Kahn, Privacy as a Legal Principle of Identity Maintenance, 33 SETON HALl L. Rev. 371 (2003). Cf. Hugh Miller, III, DNA Blueprints, Personhood, and Genetic Privacy, 8 HEALTH MATRIX 179 (1998). There are of course other approaches, and in particular more skeptical ones, such as those offered by some feminists. See, e.g., Sally F. Goldfarb, Violence Against Women and the Persistence of Privacy, 61 OHIO ST. L.J. 1 (2000). 995.

3. Edward J. Eberle, The Right to Information Self-Determination, 2001 UTAH L. REV. 965,

4. Fried, supra note 1 , at 475.

5. Jed Rubenfeld, The Right of Privacy, 102 HARV. L. REV. 737, 784 (1989).

6. See especially the recent Charter of Fundamental Rights of the European Union, arts. 7-8, 2000 O.J. (C 364) $1,10$.

7. See, e.g., Willam M. Beaney, The Right to Privacy and American Law, 31 LAW \& Contemp. Probs. 253, 255 (1966); Robert C. Post, Three Concepts of Privacy, 89 Geo. L.J. 2087 (2001).

8. Judith Jarvis Thomson, The Right to Privacy, in PHILOSOPHICAL DIMENSIONS OF PRIVACY: AN ANTHOLOGY, supra note 2, at 272, 286; see also, e.g., JEAN L. COHEN, REGULATING INTIMACY: A NEW LEGAL PARADIGM 56 (2002). 
sex. ${ }^{9}$ But the same point can be made by citing a large historical literature, which shows how remarkably ideas of privacy have shifted and mutated over time. ${ }^{10}$ Anyone who wants a vivid example can visit the ruins of Ephesus, where the modern tourist can set himself down on one of numerous ancient toilet seats in a public hall where well-to-do Ephesians gathered to commune, two thousand years ago, as they collectively emptied their bowels. ${ }^{11}$

If privacy is a universal human need that gives rise to a fundamental human right, why does it take such disconcertingly diverse forms? This is a hard problem for privacy advocates who want to talk about the values of "personhood," harder than they typically acknowledge. It is a hard problem because of the way they usually try to make their case: Overwhelmingly, privacy advocates rely on what moral philosophers call "intuitionist" arguments. ${ }^{12}$ In their crude form, these sorts of arguments suppose that human beings have a direct, intuitive grasp of right and wrong - an intuitive grasp that can guide us in our ordinary ethical decisionmaking. Privacy advocates evidently suppose the same thing. Thus, the typical privacy article rests its case precisely on an appeal to its reader's intuitions and anxieties about the evils of privacy violations. Imagine invasions of your privacy, the argument runs. Do they not seem like violations of your very personhood? Since violations of privacy seem intuitively horrible to everybody, the argument continues, safeguarding privacy must be a legal imperative, just as safeguarding property or contract is a legal imperative. Indeed, privacy matters so much to us that laws protecting it must be a basic element of human rights.

This kind of argument can certainly make a powerful impression on first reading, since it is true that we can all imagine some violation of our privacy that seems very horrible. This is especially so when the writings in question are composed by scholars with a real literary gift, like Fried.

9. Alan Westin, The Origins of Modern Claims to Privacy, in PHILOSOPHICAL DimEnsions OF PRIVACY: AN ANTHOLOGY, supra note 2, at 56, 62-63. For unconvincing doubts about the existence of public defecation, see BARRINGTON MOORE, JR., PRIVACY: STUDIES IN SOCIAL AND CULTURAL HISTORY 59-65 (1984).

10. See, e.g., ANDRÉ BerTRAND, DroIt À LA VIE PRIVÉe ET DROIT À L'IMAge 2 (1999) (discussing public defecation by early modern kings of France (citing JEAN CLAUDE BOLOGNE, HISTOIRE DE LA PUDEUR 168 (1986))); Bernard Beignier, La vie privée, in LIBERTÉS ET DROITS FONDAMENTAUX 139, 139-41 (Rémy Cabrillac et al. eds., 5th ed. 1999) (discussing nude bathing in the Seine and other early modern examples). For some doubts about the prevalence of public nudity in the premodern world, see 1 HANS PETER DUERR, DER MYTHOS VOM ZIVILISATIONSPROZESS 59-72 (1988).

11. For a discussion of communal defecation in Greco-Roman antiquity, governed by some complex social and even legal rules, see RICHARD NEUDECKER, DIE PRACHT DER LATRINE: ZUM WANDEL ÖFFENTLICHER BEDÜRFNISANSTALTEN IN DER KAISERZEITLICHEN STADT 24-39 (1994). For a discussion of Ephesus in particular, with emphasis on the posh setting, see $i d$. at 126-31. For a tourist guide, see EPHESOS: DER NEUE FüHRER 122 (Peter Scherrer ed., 1995).

12. This argument was classically offered in W.D. ROSS, THE RIGHT AND THE GOOD, at ix, xiii (Philip Stratton-Lake ed., Clarendon Press 2002) (1930). 
Nevertheless, no matter how anxiety-inducing it may be to read these authors, their arguments only carry real weight if it is true that the intuitions they evoke are shared by all human beings. Yet all the evidence seems to suggest that human intuitions and anxieties about privacy differ. We do not need to refer to the practices of exotic ancient or modern cultures to demonstrate as much: It is true even as between the familiar societies of the modern West. In fact, we are in the midst of significant privacy conflicts between the United States and the countries of Western Europe-conflicts that reflect unmistakable differences in sensibilities about what ought to be kept "private."

To the Europeans, indeed, it often seems obvious that Americans do not understand the imperative demands of privacy at all. The Monica Lewinsky investigation, in particular, with its numerous and lewd disclosures, led many Europeans to that conclusion. ${ }^{13}$ But the Lewinsky business is not the only example: There are plenty of other aspects of American life that seem to Europeans to prove the same thing. Let me offer a variety of examples from France and Germany, two countries that have been my focus in recent research, and that are my focus in this Article as well. ${ }^{14}$ Some of the things that bother French and German observers involve what Americans will think of as trivialities of everyday behavior. For example, visitors from both countries are taken aback by the ill-bred way in which Americans talk about themselves. As a French article warns visitors to the United States, America is a place where strangers suddenly share information with you about their "private activities" in a way that is "difficult to imagine" for northern Europeans or Asians. ${ }^{15}$ Americans have a particularly embarrassing habit, continental Europeans believe, of talking about salaries. It is "normal in America," an Internet site informs German tourists, for your host at dinner to ask "not just how much you earn, but even what your net worth is" $"$ - topics ordinarily quite off-limits under the rules of European

13. E.g., Jacques Lassaussois, Procès Clinton: Où va la Justice Américaine?, GAZ. PAL., Mar. 18-19, 1998, at 14 (noting that the complaint against Clinton involved "la vie privée"); Nicolas Weil, Le recours à l'intimité est de règle aux Etats-Unis, LE MONDE, Apr. 22, 2002, LEXIS, Nexis Library, Le Monde File.

14. When this Article discusses Germany during the period between World War II and reunification, it refers to West Germany unless otherwise indicated.

15. Gilles Asselin, Du mythe à la réalité des différences culturelles, FRANCE-AMERIQUE, Jan. 23-29, 1999, http://www.sococo.com/french4.htm ("Cette scène si typiquement américaine où des 'étrangers' (strangers) s'assemblent pour quelques instants et échangent rapidement des informations concernant leurs activités privées est difficile à imaginer en Asie ou dans bien d'autres pays d'Europe non méditerranéenne.").

16. Tipps für Unterwegs: USA, Essen und Trimken, at http://freenet.de/freenet/reisen/ ratgeber/unterwegs/knigge/usa.html (last visited Dec. 4, 2003) ("Wundern Sie sich nicht über Fragen nach Ihrem Einkommen oder sogar Vermögen, das ist in den USA normal."); see also FLORENCE LE BRAS, LE GUIDE DU SAVOIR-VIVRE 301 (1999) (noting that in America, "[n]e vous choquez pas si l'on vous demande le montant de vos revenus à la première rencontre"); Mitteldeutscher Rundfunk, Urlaubs-Knigge: Großbritannien, USA, at http://www.mdr.de/ hier-ab-vier/rat_und_tat/3617.html (last visited Dec. 4, 2003) ("Mit dem Thema Geld hingegen 
etiquette. ${ }^{17}$ Talking about salaries is not quite like defecating in public, but it can seem very off-putting to many Europeans nevertheless.

But it is not just a matter of the boorish American lack of privacy etiquette. It is also a matter of American law. Continental law is avidly protective of many kinds of "privacy" in many realms of life, whether the issue is consumer data, ${ }^{18}$ credit reporting, ${ }^{19}$ workplace privacy, ${ }^{20}$ discovery in civil litigation, ${ }^{21}$ the dissemination of nude images on the Internet; ${ }^{22}$ or shielding criminal offenders from public exposure. ${ }^{23}$ To people accustomed to the continental way of doing things, American law seems to tolerate relentless and brutal violations of privacy in all these areas of law. I have seen Europeans grow visibly angry, for example, when they learn about routine American practices like credit reporting. How, they ask, can merchants be permitted access to the entire credit history of customers who have never defaulted on their debts? Is it not obvious that this is a violation of privacy and personhood, which must be prohibited by law?

These are clashes in attitude that go well beyond the occasional social misunderstanding. In fact, they have provoked some tense and costly transatlantic legal and trade battles over the last decade and a half. Thus, the European Union and the United States slid into a major trade conflict over the protection of consumer data in the $1990 \mathrm{~s}$, only problematically resolved by a 2000 "safe harbor" agreement. ${ }^{24}$ Europeans still constantly complain that Americans do not accept the importance of protecting consumer privacy. ${ }^{25}$ Those tensions have only grown in the aftermath of September $11{ }^{26}$ Something similar has happened with regard to discovery in civil

wird locker umgegangen. Wundern Sie sich daher nicht, wenn man Sie nach Ihrem Einkommen fragt.").

17. E.g., Sabine Denuelle, Le Savoir-VIVRe: Guide DES RĖgles et des usages D'AUJOURD'HUI 165 (1999); LE BRAS, supra note 16, at 66.

18. See infra notes $185-190$ and accompanying text.

19. See infra notes 181-183 and accompanying text.

20. See infra notes 196-199 and accompanying text.

21. See infra note 27 and accompanying text.

22. See infra notes $218-233$ and accompanying text.

23. See infra notes $202-205$ and accompanying text.

24. At stake was the Council Directive $95 / 46$ of 24 October 1995 on the Protection of Individuals with Regard to the Processing of Personal Data and on the Free Movement of Such Data, 1995 O.J. (L 281) 31 [hereinafter Data Privacy Directive]. For further discussion, see Symposium, Data Protection Law and the European Union's Directive: The Challenge for the United States, 80 IOWA L. REV. 431 (1995). For documents on the Safe Harbor Agreement, see DANiEl J. SOlOVE \& MARC RotenberG, INFORMATION PRIVACY LAW 743-54 (2003). For the Safe Harbor Privacy Principles themselves, see Issuance of Safe Harbor Principles and Transmission to European Commission, 65 Fed. Reg. 45,666 (July 24, 2000).

25. E.g., Steven R. Salbu, The European Union Data Privacy Directive and International Relations, 35 VAND. J. TRANSNAT'L L. 655, 684 (2002); David Scheer, Europe's New High-Tech Role: Playing Privacy Cop to the World, WALL ST. J., Oct. 10, 2003, at A1.

26. E.g., Peter Gola \& Christoph Klug, Die Entwicklung des Datenschutzrechts in den Jahren 2001/2002, 55 NEUE JURISTISCHE WOCHENSCHRIFT [N.J.W.] 2431, 2431-32 (2002); Adam Clymer, Privacy Concerns: Canadian and Dutch Officials Warn of Security's Side Effects, N.Y. TIMES, Feb. 28, 2003, at A14; Scheer, supra note 25. 
procedure: American law allows parties to rummage around in each other's records in a way that seems obnoxious and manifestly unacceptable to Europeans. The result, in recent decades, has been a seething little war over discovery. ${ }^{27}$ The circulation of the nude photos of celebrities on the Internet has produced another such conflict, with Europeans acting alone to penalize Internet service providers. ${ }^{28}$

For sensitive Europeans, indeed, a tour through American law may be an experience something like a visit to the latrines of Ephesus. Correspondingly, it has become common for Europeans to maintain that they respect a "fundamental right to privacy" that is either weak or wholly absent in the "cultural context" of the United States. ${ }^{29}$ Here, Europeans point with pride to Article 8 of the European Convention on Human Rights, which protects "the right to respect for private and family life," European Union's new Charter of Fundamental Rights, which demonstratively features articles on both "Respect for Private and Family Life" and "Protection of Personal Data."31 By the standards of those great documents, American privacy law seems, from the European point of view, simply to have "failed." 32

But it is not just that Europeans resent and distrust the American approach to privacy: The reverse is also true. Anyone who has lived in the United States knows that Americans can be just as obsessively attached to their "privacy" as Europeans, sometimes defending it by resort to firearms.

27. David J. Gerber, International Discovery After Aerospatiale: The Quest for an Analytical Framework, 82 AM. J. INT'L L. 521 (1988); Abbo Junker, Der Justizkonflikt mit den USA, 26 BetrIEBS-BeraTER 1752 (1987); Christoph Paulus, Discovery, Deutsches Recht und das Haager Beweisübereinkommen, 104 ZEITSCHRIFT FÜR ZIVILPROZESS 397 (1991).

28. See infra notes $218-233$ and accompanying text.

29. Martine Bourrie-Quenillet \& Florence Rodhain, L'Utilisation de la messagerie electronique dans l'entreprise. Aspects juridiques et managériaux en France et aux Etats-Unis, La Semaine JuRidiQue Edition GenERALE [JCP], Jan. 9, 2002, nn.14-15, LEXIS, Nexis Library, La Semaine Juridique, édition générale File. For a German example, see Jürgen von Gerlach, Der Schutz der Privatsphäre von Personen des öffentlichen Lebens in rechtsvergleichender Sicht, 15/16 JURISTENZEITUNG 741, 753 (1998). For a description of the European sense that the new Charter of Fundamental Rights sets Europe apart from the United States, see Ken Gormley, Long Live the Constitution (Subject to Change), PITTSBURGH PosTGAZETTE, Nov. 17, 2002, at F1.

30. Convention for the Protection of Human Rights and Fundamental Freedoms, Nov. 4, 1950, art. 8, para. 1, 213 U.N.T.S. 221, 230 (entered into force Sept. 3, 1953). For an example of the pride and bemusement occasioned by English differences, see Chrisje Brants, The State and the Nation's Bedrooms: The Fundamental Right of Sexual Autonomy, in PERSONAL AutONOMY, THE PRIVATE SPHERE AND THE CRIMINAL LAW 117, 117 (Peter Alldridge \& Chrisje Brants eds., 2001). See also Convention for the Protection of Individuals with Regard to Automatic Processing of Personal Data, Jan. 28, 1981, Europ. T.S. No. 108 (entered into force Oct. 1, 1985); Universal Declaration of Human Rights, art. 12, G.A. Res. 217 (III)A, U.N. GAOR, 3d Sess., at 71, U.N. Doc. A/810 (1948).

31. Charter of Fundamental Rights of the European Union, supra note 6, arts. 7-8, 2000 O.J. (C 364) at 10.

32. See David A. Anderson, The Failure of American Privacy Law, in Protecting PrIVACY 139 (Basil S. Markesinis ed., 1999). 
As for American law, it too is obsessed with privacy. Indeed, some of the most violently controversial American social issues are conceived of as privacy matters. This has been true of abortion for thirty years. ${ }^{33}$ With the Supreme Court's decision in Lawrence $v$. Texas, it is now true of homosexuality as well. ${ }^{34}$ It is simply false to say that privacy doesn't matter to Americans.

In fact, let us make no mistake about it: When it comes to privacy, there are plenty of European practices that seem intuitively objectionable to Americans. Some of these have to do with seemingly minor aspects of the anthropology of everyday life, most especially involving nudity. If the Europeans are puzzled by the ill-bred way in which Americans casually talk about themselves, Americans are puzzled by the ill-bred way in which Europeans casually take off their clothes. Phenomena like public nudity in the parks of German cities are particularly baffling to Americans, but so are phenomena like the presence of female attendants in men's washrooms. It is genital nudity that Americans find most bizarre: One's genitalia are "privates" in the full sense of the word in America, and one does not ordinarily expose them in public, and certainly not before the opposite sex. Even breasts are supposed to be kept covered in the United States-as the occasional female European tourist has discovered, when arrested (or even jailed!) for sunbathing topless on an American beach. ("Those Americans are Out of their Minds!" howls a headline from a Swiss tabloid reporting one such incident from Florida.) ${ }^{35}$ Even American advertising, which doesn't stop at much, doesn't show bare breasts.

Public nudity may seem little more than a curiosity (though we shall see that it raises revealing problems in the European law of privacy). But here again, it is not just a matter of norms of everyday behavior; it is a matter of law. There are numerous aspects of European law that can seem not only ridiculous, but somewhat shocking to Americans. For example, continental governments assert the authority to decide what names parents will be permitted to give their children-a practice affirmed by the European Court of Human Rights as recently as $1996 .^{36}$ This is an application of state power that Americans will view with complete astonishment, as a manifest violation of proper norms of the protection of privacy and personhood. How can the state tell you what you are allowed to call your baby? Nor does it end there: In Germany, everybody must be formally registered with the police at all times. ${ }^{37}$ In both Germany and

33. See Roe v. Wade, 410 U.S. 113 (1973).

34. 123 S. Ct. 2472 (2003).

35. Claude Bühler, Die spinnen, die Amerikaner! Blutter Busen. Schweizerinnen Verhaftet!, BLICK ONLINE, Apr. 5, 2000 (on file with author).

36. See infra notes 321-330 and accompanying text.

37. Melderechtsrahmengesetz (MRRG), v. 24.6.1994 (BGBI. I S.1302). 
France, inspectors have the power to arrive at your door to investigate whether you have an unlicensed television. ${ }^{38}$ Evidence that Americans would regard as illegally seized is routinely considered in continental adjudication. ${ }^{39}$ In France and Germany, according to a recent study, telephones are tapped at ten to thirty times the rate they are tapped in the United States-and in the Netherlands and Italy, at 130 to 150 times the rate. ${ }^{40}$ All of this will make many an American snigger at the claim that Europeans have a superior grasp of privacy. What kind of "privacy" is there, Americans will ask, in countries where people prance around naked out of doors while allowing the state to keep tabs on their whereabouts, convict them on the basis of unfair police investigations, peer into their living rooms, tap their phones, and even dictate what names they can give to their babies?

Evidently, Americans and continental Europeans perceive privacy differently. Privacy advocates sometimes try to downplay these differences. The felt need for privacy, they insist, is in fact universal, and the only real difference is that American protections are the product of piecemeal legislation, less systematically developed than European protections as yet, but nevertheless evolving in a European direction. ${ }^{41}$ There is certainly some truth in this: There are indeed important resemblances between the systems on either side of the Atlantic. Any proper account of comparative privacy law will have to explain many similarities as well as many differences.

Nevertheless, when all is said and done, it is impossible to ignore the fact that Americans and Europeans are, as the Americans would put it,

38. In Germany, this is governed by the Rundfunkgebührenstaatsvertrag (RgebStV), v. 31.8.1991, zuletzt geändert durch Artikel 5 des Fünften Staatsvertrages zur Änderung rundfunkrechtlicher Staatsverträge v. 6.7.2000-7.8.2000 (GVBl. Berlin, S.447). For a popular website discussion of the powers of German inspectors, see Fragen und Antworten, http://www.gezneindanke.de/faq.htm (last visited Nov. 5, 2003). For France, see Decree No. 92-304 of Mar. 30, 1992, http://www.legifrance.gouv.fr/texteconsolide/FBHAD.htm; and STÉPHANE NERRANT, LA MISE HORS D'USAGE DU TÉLÉVISEUR ET L'EXIGIBILITÉ DE LA REDEVANCE DE L'AUDIOVISUEL (2000).

39. For an authoritative assessment of the state of the differences, see MIRJAN R. DAMAŠKA, EVIDENCE LAW ADRIFT 13-14, 23-24 (1997).

40. HANS-JÖRG ALBRECHT ET AL., RECHTSWIRKLICHKEIT UND EFFIZIENZ DER ÜBERWACHUNG DER TELEKOMMUNIKATION NACH DEN $\S \S 100 \mathrm{~A}, 100 \mathrm{~B}$ STPO UND ANDERER VERDECKTER ERMITTLUNGSMABNAHMEN 7 (2003), http://www.bmj.bund.de/images/11600.pdf. For an article conceding that German law is theoretically more permissive but doubting that any empirical conclusions can be drawn, see Paul M. Schwartz, German and U.S. Telecommunications Privacy Law: Legal Regulation of Domestic Law Enforcement Surveillance, 54 HASTINGS L.J. 751 (2003).

41. See, e.g., SOLOVE \& ROTENBERG, supra note 24, at 58; Joel R. Reidenberg, Setting Standards for Fair Information Practice in the U.S. Private Sector, 80 IOWA L. REV. 497 (1995). For emphasis on the piecemeal character of American law in an essay by an eminent comparatist skeptical of the future of European-style protections in the United States, see Hein Kötz, Der zivilrechtliche Persönlichkeitsschutz im anglo-amerikanischen Rechtskreis, in DAS PERSÖNLICHKEITSRECHT IM SPANNUNGSFELD ZWISCHEN INFORMATIONSAUFTRAG UND MENSCHENWÜRDE 97, 104-05 (Heinz Hübner et al. eds., 1989). 
coming from different places. At least as far as the law goes, we do not seem to possess general "human" intuitions about the "horror" of privacy violations. We possess something more complicated than that: We possess American intuitions - or, as the case may be, Dutch, Italian, French, or German intuitions. We must make some effort to explain this fact before we start proclaiming universal norms of privacy protection. In particular, we will not do justice to our transatlantic conflicts if we begin by declaring that American privacy law has "failed" while European privacy law has "succeeded." That is hogwash. What we must acknowledge, instead, is that there are, on the two sides of the Atlantic, two different cultures of privacy, which are home to different intuitive sensibilities, and which have produced two significantly different laws of privacy.

\section{DIGNITY VERSUS LIBERTY}

So why do these sensibilities differ? Why is it that French people won't talk about their salaries, but will take off their bikini tops? Why is it that Americans comply with court discovery orders that open essentially all of their documents for inspection, but refuse to carry identity cards? Why is it that Europeans tolerate state meddling in their choice of baby names? Why is it that Americans submit to extensive credit reporting without rebelling?

These are not questions we can answer by assuming that all human beings share the same raw intuitions about privacy. We do not have the same intuitions, as anybody who has lived in more than one country ought to know. What we typically have is something else: We have intuitions that are shaped by the prevailing legal and social values of the societies in which we live. In particular, we have, if I may use a clumsy phrase, juridified intuitions-intuitions that reflect our knowledge of, and commitment to, the basic legal values of our culture.

Indeed, to get a handle on our transatlantic privacy conflicts, we must begin by recognizing that continental European and American sensibilities about privacy grow out of much larger and much older differences over basic legal values, rooted in much larger and much older differences in social and political traditions. The fundamental contrast, in my view, is not difficult to identify. In one form or another, it is a contrast that has been noticed by observers of the transatlantic scene for a century. ${ }^{42}$ It is the

42. See BERNARD BEIGNIER, LE DROIT DE LA PERSONNALITÉ 60-61 (1992) (contrasting the French focus on dignity with the characteristically American focus on liberty); EDWARD J. EBERLE, Dignity AND LIBERTY: CONSTITUTIONAL VISIONS IN GERMANY AND THE UNITED STATES 6-7 (2002); J. KOHLER, DAS EIGENBILD IM RECHT 7 (1903) (noting that the American "right of privacy" is a mere right to remain hidden, which is inadequate); id. at 17 (explaining that the correct German view is that one's image must be protected against "tasteless, insulting or degrading" appropriation or exposure); FRANÇOIS RIGAUX, LA PROTECTION DE LA VIE PRIVÉE ET DES AUTRES BIENS DE LA PERSONNALITÉ 698 (1990) (noting the absence of concern with honor in 
contrast between two conceptions of privacy most recently distinguished by Robert Post: between privacy as an aspect of dignity and privacy as an aspect of liberty. ${ }^{43}$

Continental privacy protections are, at their core, a form of protection of a right to respect and personal dignity. The core continental privacy rights are rights to one's image, name, and reputation, ${ }^{44}$ and what Germans call the right to informational self-determination - the right to control the sorts of information disclosed about oneself. ${ }^{45}$ These are closely linked forms of the same basic right: They are all rights to control your public image-rights to guarantee that people see you the way you want to be seen. They are, as it were, rights to be shielded against unwanted public exposure - to be spared embarrassment or humiliation. The prime enemy of our privacy, according to this continental conception, is the media, which always threatens to broadcast unsavory information about us in ways that endanger our public dignity. But of course, this concern does not end with media exposure. Any other agent that gathers and disseminates information can also pose such dangers. In its focus on shielding us from public indignity, the continental conception is typical of the continental legal world much more broadly: On the Continent, the protection of personal dignity has been a consuming concern for many generations.

By contrast, America, in this as in so many things, is much more oriented toward values of liberty, and especially liberty against the state. At its conceptual core, the American right to privacy still takes much the form that it took in the eighteenth century: It is the right to freedom from intrusions by the state, especially in one's own home. ${ }^{46}$ The prime danger,

American law). The relative absence of honor-oriented dignity in America has also been noted by Jeffrey Rosen, in passages citing my own earlier work. Jeffrey Rosen, The Purposes of Privacy: A Response, 89 GEO. L.J. 2117, 2125-27 \& nn.21-22 (2001) (citing James Q. Whitman, Enforcing Civility and Respect: Three Societies, 109 YALE L.J. 1279, 1293, 1307-09 (2000)).

43. These are two of the three concepts identified in Post, supra note 7, at 2087.

44. European scholars sometimes treat the right to one's image and the right to privacy as different, if always closely related, interests. This is particularly because of the issues raised by commercialization of one's image. See, e.g., Florence Bouvard, La Commercialisation de l'Image de la Personne Physique, in IMAGE ET DROIT 375, 380-84 (Pascale Bloch ed., 2002). Nevertheless, French jurisprudence tends to see it differently. See, e.g., Isabelle de Lamberterie \& Xavier Strubel, L'Image Manipulée, in IMAGE ET DROIT, supra, at 335, 349-50 (stating that today, manipulation of a person's image is a subject of privacy !aw). And indeed, the spirit of both bodies of law is much the same. It is justifiable to treat them as, at core, a single body of law, concerned in all of its aspects with the public image.

For the codification of the relevant German law, see $\S \S 22-23$ KUNSTURHEBERGESETZ [KUG] (amended 2001). For detailed discussion on the current state of German law, see URHEBERRECHT KOMMENTAR 926 (Gerhard Schricker ed., 1999).

45. For detailed discussion of this point, see EBERLE, supra note 42, at 87-92. For the general outlines of the German right, see $\S 823$, at 61 BÜRGERLICHES GESETZBUCH [BGB] (Otto Mühl \& Walther Hadding eds., 1998) (commentary by Zeuner).

46. For the commonplace view that this is the origin of the American right to privacy, see, for example, JefFrey Rosen, THE UnWANTEd GaZE: THE DeSTRUCTION OF PRIVACY IN AMERICA 5 (2000). 
from the American point of view, is that "the sanctity of [our] home[s]," in the words of a leading nineteenth-century Supreme Court opinion on privacy, will be breached by government actors. ${ }^{47}$ American anxieties thus focus comparatively little on the media. Instead, they tend to be anxieties about maintaining a kind of private sovereignty within our own walls.

Such is the contrast that lies at the base of our divergent sensibilities about what counts as a "privacy" violation. On the one hand, we have an Old World in which it seems fundamentally important not to lose public face; on the other, a New World in which it seems fundamentally important to preserve the home as a citadel of individual sovereignty. What Europeans miss in Americans is a sense of the demands of public face; indeed, Europeans have been denouncing American law on that ground since at least 1903. ${ }^{48}$ When Americans seem to continental Europeans to violate norms of privacy, it is because they seem to display an embarrassing lack of concern for public dignity-whether the issue is the public indignity inflicted upon Monica Lewinsky by the media, or the self-inflicted indignity of an American who boasts about his salary. Conversely, when continental Europeans seem to Americans to violate norms of privacy, it is because they seem to show a supine lack of resistance to invasions of the realm of private sovereignty whose main citadel is the home- - whether the issue is wiretapping or baby names. The question of public nudity presents the contrast in piquant form. To the continental way of seeing things, what matters is the right to control your public image-and that right may include the right to present yourself proudly nude, if you so choose. To the American mind, by contrast, what matters is sovereignty within one's own home; and people who have shucked the protection of clothing are like people who have shucked the protection of the walls of their homes, only more so. They are people who have surrendered any "reasonable expectation of privacy." 49

Now, let me emphasize that this contrast is not absolute. These are complex societies, which are home to a variety of sensibilities, concerns, traditions, and mutual influences. There are certainly some Americans who find the European idea of dignity appealing. This is notably true of Justice Kennedy, whose opinion for the Court in Lawrence v. Texas expresses admiration for European approaches, and who tries energetically to found his opinion on ideals of both liberty and dignity. ${ }^{50}$ For that matter, there are no doubt Europeans who find the characteristic American approach appealing. Moreover, it is certainly the case that both forms of the protection of privacy are in force to some extent on both sides of the

47. Boyd v. United States, 116 U.S. 616, 630 (1886).

48. See KOHLER, supra note 42 , at 7.

49. See infra notes $240-242$ and accompanying text.

50. See 123 S. Ct. 2472, 2483 (2003) (Kennedy, J.). 
Atlantic: There are some protections against the media and the like in the United States, and there are certainly some American tort cases protecting people's public image. ${ }^{51}$ As for Europe: There are certainly some quite farreaching protections against the state there, and there is certainly law protecting people within the bounds of the home. ${ }^{52}$

So it would be wrong to say that there is some absolute difference between American and continental European law. But the issue is not whether there is an absolute difference. Comparative law is the study of relative differences. Indeed, it is the great methodological advantage of comparative law that it can explore relative differences. No absolute generalization about any legal system is ever true. It would be false, for example, to say that American law is hostile to the social welfare state: It is easy to think of exceptions to that generalization. But what is true is that American law is more hostile to the social welfare state than continental law-and that is a statement that is not only true, but highly important to understanding the world in which we live.

In comparative privacy law, too, it is the relative differences that matter. Americans and Europeans certainly do sometimes arrive at the same conclusions. Nevertheless, they have different starting points and different ultimate understandings of what counts as a just society. If I may use a cosmological metaphor: American privacy law is a body caught in the gravitational orbit of liberty values, while European law is caught in the orbit of dignity. There are certainly times when the two bodies of law approach each other more or less nearly. Yet they are consistently pulled in different directions, and the consequence is that these two legal orders really do meaningfully differ: Continental Europeans are consistently more drawn to problems touching on public dignity, while Americans are consistently more drawn to problems touching on the depredations of the state. Indeed, as our many transatlantic conflicts suggest, the distances between us can often stretch into the unbridgeable.

It should be obvious enough that this is not a contrast that we can understand by reflecting on the supposed universal intuitive imperatives of "personhood," or of "the integrity of the person." One's sense of personhood can be grounded just as much in an attachment to liberty as in an attachment to dignity. Maybe Europeans feel that their personhood is confirmed by the fact that their bosses are obliged to respect their privacy in the workplace, or by the fact that they can freely strip and sun themselves in central Berlin. That does not prevent Americans from feeling that their personhood is confirmed when they sit at home, a shotgun across their knees, determined to resist taxation.

51. See infra notes 243-257 and accompanying text.

52. See Brants, supra note 30. 
No, the issue is not that one side of the Atlantic has discovered true "personhood," while the other lags behind. Something else is going on. The only way to think straight about these differences is to reflect on the core social values of dignity or liberty. The comparative law of privacy is not about the intuitive preconditions of personhood, but about contrasting political and social ideals. In the United States those political and social ideals revolve, as they have for generations, primarily around our suspicions of the police and other officials, while on the Continent they revolve unmistakably around one's position in society, one's "dignity" and "honor."

Such is the contrast this Article explores. Its focus is primarily on the Continent, whose world is too little known among Americans, with only an abbreviated sketch of American law. But I hope that even a sketch of American law will stand out in much bolder and more revealing relief when placed against the continental background.

\section{THE EUROPEAN TRADITION OF DIGNITY: LEVELING UP}

The political and social values of "dignity" and "honor" are indeed what is at stake in the continental concept of privacy, in ways that we can only understand if we dig deeply into continental traditions. That is what I propose to do in the next few Parts of this Article, focusing, as I have done in a series of related publications, on Germany and France, the two dominant legal traditions of the Continent. Here I must begin by summarizing work I have published on a variety of aspects of European "dignity."

Where do the peculiar continental anxieties about "privacy" come from? To understand the continental law of privacy, we must start by recognizing how deeply "dignity" and "honor" matter in continental law more broadly. Privacy is not the only area in which continental law aims to protect people from shame and humiliation, from loss of public dignity. The law of privacy, in these continental countries, is only one member of a much wider class of legal protections for interpersonal respect. The importance of the value of respect in continental law is most familiar to Americans from one body of law in particular: the continental law of hate speech, which protects minorities against disrespectful epithets. But the continental attachment to norms of respect goes well beyond hate speech. Minorities are not the only ones protected against disrespectful epithets on the Continent. Everybody is protected against disrespect, through the continental law of "insult," a very old body of law that protects the individual right to "personal honor." Nor does it end there. Continental

53. Whitman, supra note 42 , at $1295-360$. 
law protects the right of workers to respectful treatment by their bosses and coworkers, through what is called the law of "mobbing" or "moral harassment." This is law that protects employees against being addressed disrespectfully, shunned, or even assigned humiliating tasks like xeroxing. ${ }^{54}$ Continental law also protects the right of women to respectful treatment through its version of the law of sexual harassment. It even tries to protect the right of prison inmates to respectful treatment, as I have noted in a recent book, to a degree almost unimaginable for Americans. ${ }^{55}$

Why does continental law work so hard to guarantee norms of "respect," "dignity," and "personal honor" in so many walks of life? This is a question to which I believe we must give a different answer from the one Europeans themselves commonly give. Europeans generally give a dramatic explanation for why dignity figures so prominently in their law: They assert that contemporary continental dignity is the product of a reaction against fascism, and especially against Nazism. ${ }^{56}$ Having experienced the horrific indignities of the 1930s and 1940s, continental societies, Europeans say, have mended their ways. Europe has dignity today because Europe was traumatized seventy years ago. This is an answer that is often embraced by Americans, too-most notably Robert Kagan, in his recent bestseller Of Paradise and Power. ${ }^{57}$

And indeed, it is hard to resist a story with so much natural drama. But I have tried to demonstrate that the real story is different, and much more complicated. The European culture of dignity is not well-understood as any kind of simple reaction against fascism; even the place of fascism in the making of European dignity is more ambiguous than one might suppose. In fact, the history of the continental law of dignity begins long before the postwar period. It begins in the eighteenth, and even the seventeenth, centuries. The continental societies that we see today are the descendants of the sharply hierarchical societies that existed two or two-and-a-half centuries ago- of the aristocratic and monarchical societies of which the France of Louis XIV was the model. In point of fact, continental law has enforced norms of respect and dignity for a very long time. In earlier centuries, though, only persons of high social status could expect their right to respect to be protected in court. Indeed, well into the twentieth century, only high-status persons could expect to be treated respectfully in the daily life of Germany or France, and only high-status persons could expect their "personal honor" to be protected in continental courts. Members of the

54. See Gabrielle S. Friedman \& James Q. Whitman, The European Transformation of Harassment Law: Discrimination Versus Dignity, 9 COLUM. J. EUR. L. 241 (2003).

55. James Q. Whitman, Harsh Justice: CRiminal Punishment and the Widening DIVIDE BETWEEN AMERICA AND EUROPE 84-92 (2003).

56. See, e.g., BEIGNIER, supra note 42 , at 7 ; infra notes 126,161 and accompanying text.

57. Robert Kagan, OF PaRadise and POWER: AMERICA and EuROPE IN THE NeW WORLD ORDER 11, 58-62 (2003). 
lower orders-the vast majority of the population-certainly had no meaningful right to respect. Quite the contrary. ${ }^{58}$

What we see in continental law today is the result of a centuries-long, slow-maturing revolt against that style of status privilege. Over time, it has come to seem unacceptable that only certain persons should enjoy legal protections for their "dignity." Indeed, the rise of norms of respect for everybody - even minorities, even prison inmates-represents a great social transformation on the Continent. Everybody is now supposed to be treated in ways that only highly placed and wealthy people were treated a couple of centuries ago. Germany and France have been the theater of a leveling up, of an extension of historically high-status norms throughout the population. As the French sociologist Philippe d'Iribarne has elegantly put it, the promise of modern continental society is the promise that, where there were once masters and slaves, now "you shall all be masters!",59

The uncomfortable paradox, as I have tried to show, is that much of this leveling up took place during the fascist period, for fascist politics involved precisely the promise that all members of the nation-state would be equal in "honor"-that all racial Germans, for example, would be "masters." "Fo For that very reason, some of the fundamental institutions of the continental law of dignity experienced significant development under the star of fascism. In fact, the fascist period, seen in proper sociological perspective, was one stage in a continuous history of the extension of honor throughout all echelons of continental society.

This long-term secular leveling-up tendency has shaped continental law in a very fundamental way. ${ }^{61}$ Contemporary continental hate speech protections, for example, can be traced back to dueling law: In the nineteenth century, continental courts protected the right to respect only of the dueling classes. Today they protect everybody's right to respect; indeed, the rules of dueling have had a striking influence in the Continent, sometimes being imported bodily into the law. Contemporary protections for prison inmates have a very similar history: In the eighteenth century, continental law maintained sharp distinctions between high- and low-status punishments. If executed, high-status offenders were beheaded, while low-

58. See WHITMAN, supra note 55, at 101-42; Whitman, supra note 42 , at $1320-30$.

59. PHILIPPE D'IRIBARNE, VOUS SEREZ TOUS DES MAÎTRES!: LA GRANDE ILLUSION DES TEMPS MODERNES (1996).

60. James Q. Whitman, On Nazi 'Honour' and the New European 'Dignity,' in DARKER LEGACIES OF LAW IN EUROPE: THE SHADOW OF NATIONAL SOCIALISM AND FASCISM OVER EUROPE AND ITS LEGAL TRADITIONS 243, 251-62 (Christian Joerges \& Navraj Singh Ghaleigh eds., 2003).

61. In my other writings on this subject, I have argued that American law is the product of a converse leveling-down tendency. See WhITMAN, supra note 55; Whitman, supra note 42. I do not pursue the same argument here because I do not believe that we can clearly identify historically low-status patterns of privacy protection that have generalized themselves in the United States in the way that other historical low-status practices have. 
status offenders were hanged; if spared, high-status offenders were housed in comfortable apartments, while low-status offenders were subjected to degrading penal slavery. In the two centuries since the French Revolution, the old high-status forms of punishment have gradually been generalized to all: All inmates are now treated according to a regime of imprisonment that was once reserved to figures like Voltaire. ${ }^{62}$

Such has been the history of the continental law of respect. It is a history, as I have tried to show, that has always been closely linked with the history of continental etiquette, which also began as a set of rules for courtiers, only to be generalized to the entire population. Indeed, the rules of etiquette, like the rules of dueling, have sometimes exercised a direct influence on the making of the European law of respect, which is often concerned with matters like the legal right to be addressed as "vous" or "Sie." 63

This world of continental respect is also the world of continental privacy. When continental lawyers speak of "privacy" as a set of rights over the control of one's image, name, and reputation, and over the public disclosure of information about oneself, they are speaking to these selfsame continental sensibilities. To be sure, they are talking about privacy in a way that many Americans also talk about it. The idea that privacy is really about the control of one's public image has long appealed to the most philosophically sophisticated American commentators, from Alan Westin, ${ }^{64}$ to Charles Fried, ${ }^{65}$ to Jeffrey Rosen, ${ }^{66}$ to Thomas Nagel. ${ }^{67}$ In its most compelling form, the claim has come from Robert Post: For Post, privacy law protects norms of dignity that are "civility rules," just like the norms of etiquette; and without the protection of such norms, he argues, no society can maintain any form of community ${ }^{68}$ Moreover, similar ideas can already be found in the most famous of American articles, Samuel Warren and Louis Brandeis's 1890 The Right to Privacy. ${ }^{69}$ All of these American writers have viewed the danger in the violation of our "privacy" as the danger that we will lose the capacity to control what Erving Goffman famously called our "presentation of self"-our image before the eyes of

62. WHITMAN, supra note 55, at 9-10.

63. See Whitman, supra note 42, at 1299-300.

64. ALAN F. WESTIN, PRIVACY AND FREEDOM (1967).

65. Fried, supra note 1.

66. ROSEN, supra note 46.

67. Thomas Nagel, Concealment And ExPosure 4 (2002); see also Stanley I. Benn, Privacy, Freedom, and Respect for Persons, in NOMOS XIII: PRIVACY 1 (J. Roland Pennock \& John W. Chapman eds., 1971) (grounding privacy in a right to autonomy and respect).

68. ROBERT C. POST, The Social Foundation of Privacy, in CONSTITUTIONAL DOMAINS: DEMOCRACY, COMMUNITY, MANAGEMENT 51, 86 (1995).

69. Samuel D. Warren \& Louis D. Brandeis, The Right to Privacy, 4 HARV. L. REV. 193 (1890). 
others in society. ${ }^{70}$ All of them have thought of our right to privacy, perhaps a shade paradoxically, as our right to a public image of our own making, as the right to control our public face. Indeed, it is precisely for that reason that they have insisted on the connection between privacy and personhood.

So the prevailing continental conception is also the one that most thoughtful American commentators on privacy and "personhood" have found the wisest and most sophisticated. But if this conception has triumphed in continental law, it is not because European lawyers possess any unique measure of wisdom or sophistication. Nor is it because they alone recognize the norms that are necessary for the maintenance of community. Human communities can be founded on the widest variety of norms. As for law: It is not about the worldly realization of wisdom or sophistication as such. Law is about what works, what seems appealing and appropriate in a given society, and the conception of privacy as control of one's "image" has succeeded because it fits into continental social traditions, and into a quotidian continental culture of respect. Continental privacy is "continental" in much the way that continental hate speech law is "continental," and in much the way that continental prison law is "continental." For that matter, it is "continental" in much the way that continental etiquette is "continental"--for, pace Professor Post, the norms of "civility," far from being universal, vary dramatically from community to community.

Indeed, etiquette makes, as so often, a striking example of the social roots of European dignitary law. It is not an accident that both etiquette and privacy law show the same anxious preoccupation with "public image." Thus, it is common for continental etiquette guides to open with a section called "how we present ourselves before the world","71 or "the politesse of appearances"; ${ }^{72}$ or more broadly a section on how to maintain the correct external look and manners. ${ }^{73}$ Rules about how to dress and how to wear makeup are part of continental etiquette just as are rules about how to comport oneself on the street, at the table, or in the workplace. ${ }^{74}$ Continental etiquette is indeed overwhelmingly about "the presentation of self in everyday life," just like continental privacy law. In fact, continental authors sometimes consciously present etiquette and privacy law as related subjects: For example, you can buy a book for German journalists,

70. ERving Goffman, The PRESEntation of SElf in EVERyday Life (1959).

71. Gian AMEdeo Rossini, Il. Grande Libro del Galateo [7] (1997) ("Come ci si presenta al mondo.").

72. DENUELLE, supra note 17 , at 9-22.

73. GiSEla TAuTZ-WiebneR, LebensART: ERFolgreich UND BELIEBT DURCH GUTE UMGANGSFORMEN 15-57 (1993).

74. See, e.g., Hermine de Clermont-Tonnerre, Politesse Oblige. Le SAVoir-Vivre AUJOURD'HUI 15-49 (1996); ROSEMARIE WREDE-GRISCHKAT, HOHE SCHULE DES GUTEN BENEHMENS. ERFOLGREICH UND SICHER AUF JEDEM PARKETT 23-82, 105-68 (1995). 
published by the leading German newspaper, called Kleiner Knigge des Presserechts - a little etiquette book of press law-which treats all of the standard questions of privacy as questions of good manners. ${ }^{75}$

But it is not just that the conception of privacy as control over one's image fits into the traditions of continental etiquette. It fits into the continental traditions of dignity, respect, and personal honor more broadly. ${ }^{76}$ As we shall see shortly, continental privacy law, like most continental law of respect, developed largely from the law of insult. It even has connections with dueling. It has a Nazi history. Most generally, it fits within the tradition of status revolution that has shaped so much of continental law - the revolution of leveling up. Indeed, as I want to insist in this Article, continental privacy protections offer perhaps the paradigmatic example of high-status norms that have been generalized to the wider population. For as we can all instantly recognize, the conception of privacy as control over one's public image is a conception originally and primarily concerned with the doings of very high-status persons.

Indeed, critics have always insisted that a notion of privacy as a right to control one's "image" is a notion primarily of interest to people of very high status-to personages like the Warrens of Boston, or for that matter like Princess Caroline of Monaco, whose affairs still provide constant grist for the continental privacy mill. The conception of privacy as control of one's image rests, at base, on the idea that one ought to be able to keep one's name and picture out of the newspapers. This is obviously a conception that matters primarily to members of "society" as the term is used in the phrase "society pages."

And that is just what we see in continental privacy law: a high-status conception of privacy, a "society" conception of privacy. In fact, it is almost comical to read off the names in the captions of the leading postwar continental cases. Open a book on comparative privacy law, and here are the names you will see: Princess Soraya of Iran, ${ }^{77}$ Princess Caroline of Monaco, ${ }^{78}$ Prince Ernst August of Hanover. ${ }^{79}$ There is a remarkable disproportion of royalty in continental privacy thinking. Down to this day, in fact, German texts list royalty first among the classes of "public figures"

75. RUdOlF GERHARDT \& ERICH STEFFEN, KLEINER KNIGGE DES PRESSERECHTS (2002).

76. For similar, but sketchy, historical observations, see Heinz Holzhauer, Zur Vorgeschichte des allgemeinen Persönlichkeitsrechts, in RECHT DER PERSÖNLICHKEIT 51, 62-71 (Hans-Uwe Erichsen et al. eds., 1996).

77. Donald P. Kommers, The Constitutional JuRisprudence of the Federal REPUBLIC OF GERMANY 124-28 (2d ed. 1997).

78. Entscheidungen des Bundesgerichtshofes in Zivilsachen [BGHZ] [Supreme Court] 131, 332 (F.R.G.); see also BVerfG, 1 BvR 653/96, v. 15.12.1999, 53 N.J.W. 1021 (2000).

79. For a description of his peculiar importance, and for citations to additional sources, see Jörg SOEHRING, PRESSERECHT: RECHERCHE, DARSTEllung UND HAFTUNG IM RECHT DER PRESSE, DES RUNDFUNKS UND DER NEUEN MEDIEN 428 (3d ed. 2000). 
who require special treatment in the law of privacy, ${ }^{80}$ while French texts, the product of a deeper democratic tradition, only list royalty second, after politicians. "Members of the aristocracy" ${ }^{81}$ too are presented as classes that had to be specially treated. These are textbooks written in worlds that remain very different from ours. Even the nonroyals and nonaristocrats involved in the leading European privacy cases are often very prominent persons indeed: Hjalmar Schacht, former Nazi finance minister, ${ }^{83}$ Robert Barcia, longtime eminence grise of the French Trotskyite party. ${ }^{84}$ Indeed, an American cynic who wants to mock the vaunted continental commitment to privacy will point gleefully at these names. At core, the American will sneer, the continental protection for privacy grants everyone alike the right to be safe from paparazzi. Does this really have anything to do with the values of a true democracy? At best, continental privacy law is not a form of protection for universal human "personhood," but a means of regulating the relations between celebrities and the rest of us.

Nevertheless, as I want to insist, to take that mocking attitude would be to underestimate the moral claims of European leveling up, as it expresses itself in privacy law. There is more to the law than its practical impact. The law also aims to express social values - the continental law of privacy as much as or more than any other body of law. What the continental law of privacy expresses is the fundamental social importance of a commitment to extend royal treatment to everyone. Indeed, we cannot understand our transatlantic conflicts if we do not recognize the authentically wide social application of "society" privacy in continental law. Over the past several generations, the basic commitment to control of one's public image has been extended well beyond its origins in the problems of the Princess Carolines of the world, in ways that do indeed affect the lives of ordinary people. This is most especially true of the areas where the conflicts between continental and American norms are most heated-areas like consumer data, credit reporting, public nudity, and the dignity of criminal offenders. These are all realms of life in which continental law has forcefully extended privacy protections to noncelebrities and nonroyals. Control of one's

80. See, e.g., Peter RAUE, PersönlichkeItSRechte: DIE VerteIdigung DeR PERSÖNLICHEN EHRE 11-12 (1997). For an older example, see A. OSTERRIETH, DAS URHEBERRECHT AN WERKEN DER BILDENDEN KÜNSTE UND DER PHOTOGRAPHIE 173 (Bruno Marwitz ed., $2 \mathrm{~d}$ ed. 1929). One notes with bemusement that within the second category of public figures described in this text, "professors and academics" rank second after politicians, and ahead of "writers, artists, virtuosos, actors." Ah Germany!

81. BERTRAND, supra note 10, at 26-32.

82. SOEHRING, supra note 79 , at 432 (noting that members of the aristocracy were not ipso facto public figures, but were peculiarly liable to become public figures on account of their activities or accomplishments).

83. See Stefan GotTWALD, Das Allgemeine PersönlichKeITSReCht: EIN ZEITGESCHICHTLICHES ERKLÄRUNGSMODELL 81 -85 (1996).

84. Barcia c. S.A. Groupe Express, No. 2000/14309, slip op., CA Paris, le ch., Sept. 20, 2001. 
"image," in the continental mind, now includes more than everybody's right to keep one's names out of the newspapers. It also includes everybody's right to control the use of one's consumer data and the like, everybody's right to privacy in the workplace, everybody's right (if one should need it) to respectful imprisonment, and more. Continental privacy law is, as it were, "society" privacy for everybody.

One recent German popular guide to the law proudly puts it in this way, in language that deserves to be underlined. Privacy rights, the book explains, are part of a larger law of the "defense of personal honor," and nowadays it's not just the "royal houses" whose image is threatened; "everybody is in danger." 85 Silly enough-but also truly appealing in its way. Of course it matters to insist that everybody counts the same way royalty does, from racial minorities and prison inmates on up through the ranks of society.

\section{THE RISE OF FRENCH PRIVACY LAW}

There is no better way to grasp this continental social ideal than to trace its historical development, from its origins in the nineteenth-century world of dueling, through the Nazi period, and on into its modern forms. Continental jurists have always tried to understand "privacy" as a species of personal honor. In particular, going back to the nineteenth century, continental thinking has always treated privacy as a value primarily threatened by two forces: the excesses of the free press and the excesses of the free market. From the point of view of the nineteenth-century continental tradition, there were two things that peculiarly menaced a respectable person's "honor": loose talk, and the grubbiness of the world of buying and selling. Continental privacy law has been shaped by a longstanding battle waged against both. Indeed, the history of continental privacy law has been, in essence, the history of the resistance, in the name of "honor," to two of the fundamental values of American liberty: the value of free speech, and the value of private property as distributed through the market.

French law developed mostly over the period of 1790 to 1900 , while German law developed later, from about 1880 to 1960 . The two traditions have peculiar emphases. French law has had to struggle in a distinctive way with France's recurrent periods of sexual license, and German law was peculiarly formed by the events of the Nazi period and after. Nevertheless, both remain recognizably continental, and recognizably different from

85. RAUE, supra note 80 , at 11-12; $f$. ROSEN, supra note 46, at 202 (stating that, in America, "private citizens run the risk of being treated like celebrities in the worst sense, vilified rather than celebrated"). 
American law. In particular, in both countries, the law of privacy protection was built using the doctrinal resources of the classic continental law of personal honor - the law of insult-in tandem with the law of artistic and intellectual property.

Let us begin with France. French ideas about the protection of "private life" date at least to the early modern period. High-status families have always sought to protect their privacy in France, and they have sometimes succeeded. For example, for several centuries the French nobility successfully fought off efforts to require public registration of the mortgages on their real property, which would have exposed their finances for inspection. ${ }^{86}$ There were other ways, too, in which high-status ancien régime Frenchmen sought to protect their privacy. ${ }^{87}$

But the modern history of French privacy protection, which has been sadly neglected, ${ }^{88}$ begins with the Revolution, and most particularly with the introduction of freedom of the press. Freedom of the press has always made leading French observers nervous, even ones with very liberal beliefs. Thus, the first French effort to create constitutional protections for freedom of the press was already accompanied by a proviso intended to guarantee that "private life," as an integral part of personal "honor," would not be subject to press depredations. The Constitution of 1791, the first detailed revolutionary blueprint for a new kind of European liberal society, included extensive protections for freedom of the press. But at the same time, it added protections against "calumnies and insults relative to private life." 89 One of the draftsmen of the Constitution, the Jacobin Jérôme Pétion, speaking during the flush of revolutionary excitement in August of 1791, explained the intent of the new document in this way: A vigorous free press was unconditionally necessary for the maintenance of liberal government. ${ }^{90}$ Nevertheless, it was true that those very press liberties threatened the "private person." whose private lives had been violated some legal recourse against "insults." To do so would not undermine the freedoms gained in the Revolution. On the contrary, it would achieve a revolutionary end. In fact, the "new

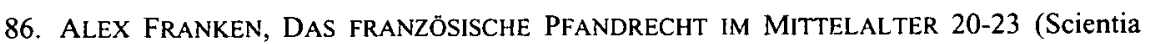
Verlag 1969) (1879); JULES MINIER, PRECIS HISTORIQUE DU DROIT FRANÇAIS: INTRODUCTION A L'ETUDE DU DROIT 55, 637-38 (Paris, A. Maresq et E. Dujardin 1854).

87. See Orest Ranum, The Refuges of Intimacy, in 3 A HISTORY OF PRIVATE LIFE 207, 210-37 (Arthur Goldhammer trans. \& Roger Chartier ed., 1989).

88. French texts generally treat the protection of privacy as a phenomenon dating only to the second half of the nineteenth century. See, e.g., BEIGNIER, supra note 42, at 46-47.

89. CONSTITUTION du 3 septembre 1791, tit. III, ch. V, art. 17 ("Les calomnies et injures contre quelques personnes que ce soit relatives aux actions de leur vie privée, seront punies sur leur poursuite.").

90. J. Pétion, Discours sur la liberté de la Presse, 16 COURIER DE PROVENCE 169 (1791).

91. J. Pétion, Suite du discourse sur la liberté de la Presse, 16 COURIER DE PROVENCE 198 (1791) 
doctrine," with its emphasis on the rights of ordinary private persons, directly "contradicted the ideas of the ancien régime." A2 After all:

[In the ancien régime] the least offense given to what would be called the honor of a man of position was a serious crime, which could not be punished severely enough, while an offense to a simple citizen hardly received any attention on the part of the law; but for that very reason, the new doctrine is all the more correct and in conformity with the principles of the new order of things. ${ }^{93}$

The first manifestation of "privacy" in French law thus came in the form of a classic statement of the ambition to bring everybody up in status. The introduction of privacy protections was indeed akin to contemporary developments like the introduction of the guillotine. The guillotine arrived shortly after Pétion gave this speech, as a means of extending the high-status privilege of beheading to all persons. ${ }^{94}$ It too belonged to a "new order of things" in which everybody's honor was to be protected.

These remained the characteristic ideas of French privacy law thereafter-notably in 1819 , the year of the passage of the first postNapoleonic law lifting press censorship. As the Restoration successfully established its authority, the government of Louis Philippe consented to tolerate a freer press. But the idea of press freedom continued to trouble even liberally minded Frenchmen, and the classic nineteenth-century statement of the importance of privacy emerged as soon as press censorship was even partially lifted. In fact, it came once again from a leading advocate of press reform: Pierre-Paul Royer-Collard, a leading politician, professor of philosophy at the Sorbonne, and hero of French liberalism. Royer-Collard, even as he defended press liberalization, gave a famous speech warning that private life had to be "walled off" ("murée") against the danger of "calomnie," insult. The press, he said, had to be free, but the only proper realm for press freedom was the public sphere, and even true facts about private life could not be lawfully published. ${ }^{95}$ In the course of his speechifying, Royer-Collard produced a classic morsel of French metaphoric oratory-“private life must be walled off?"- that established itself as a standard continental slogan, repeated well into the twentieth century. ${ }^{96}$

92. Id. at 199 .

93. Id.

94. WHITMAN, supra note 55 , at 109-13.

95. See 1 de Barante, LA VIE POLITIQUe DE M. Royer-COllard, SES DisCours ET SES ÉCRITS 474-75 (Paris, Didier 1863).

96. E.g., OSTERRIETH, supra note 80, at 179; ALBERT VAUNOIS, LA LIBERTÉ DU PORTRAIT 6 (Paris, Chevalier-Marescq 1894). 
To be sure, what Royer-Collard produced was an oration, not a law, and for several decades thereafter there was little by way of protection for privacy in the letter of French law. For that reason, French legal historians treat the period of the 1820 s through the 1840 s as a time when there was simply no protection for private life. ${ }^{97}$ But it is a real mistake to conclude from the absence of law about privacy that no protection existed. In this period, one's private affairs remained a matter of one's honor, and one's honor remained a thing more precious, as French authors regularly declared, than life itself. During the decades after 1819 , the primary means of protecting one's honor was through the duel, and "private life" was defended, at least sometimes, in exactly that way. Thus, the dueling literature listed "the delicacy of private life" among the aspects of "honor" that demanded protection. ${ }^{98}$ And it was indeed so protected, as we can see from the example of one of the most famous dueling incidents in French history, the case of the Duchess of Berry. The Duchess was a leading royalist agitator and mother of the Comte de Chambord, the pretender to the throne. While she was being held prisoner in a fortress in 1833, after an attempt to foment rebellion, it was publicly revealed that she was pregnant-even though she had been widowed for some years. As Louis Blanc described the resulting scandal, the Duchess's "intimate life" was "exposed to the insulting commentaries of the multitude"; "[i]n vain," he added, "had she counted upon that solidarity of honor that reigns among relatives, even ones of obscure social condition, and that, protecting families, saves them from scandal by keeping secrets." ${ }^{\circ 9}$ Her family did not defend her, but several royalists did: This famous violation of royal privacy caused more than one duel between royalists and republicans-including one in which several royalist journalists challenged several republican ones to a gigantic duello, ${ }^{100}$ and another in which the eminent General Bugeaud killed a member of the Chamber of Deputies. ${ }^{101}$ The honor of "private life" was not protected by the law in the 1830 s, but it was defended.

By the mid-nineteenth century, though, this extravagant world of dueling honor began slowly to fade, and questions of private life began to migrate into the law. In part this reflected uneasiness about the traditions of dueling, as commentators demanded that questions of honor be settled in

97. BERTRAND, supra note 10 , at 2.

98. 2 EUGĖNE CAUCHY, Du DUEL, CONSIDÉRÉ DANS SES ORIGINES ET DANS L'ÉTAT ACTUEL DES MOEURS 41 (Paris, Guillaumin 1863).

99. 4 Louis BlanC, Histoire DE Dix ANS, 1830-1840, at 22-23 (Paris, Pagnerre 1844).

100. For an account of the incident, see 1 FougerouX DE CAMPIGNEULLES, HISTOIRE DES DUELS ANCIENS ET MODERNES 385-87 (Paris, Tessier/Cherbuliez 1835).

101. Bugeaud de la Piconnerie, in THE 1911 EDITION ENCYCLOPEDIA, at http://www.1911 encyclopedia.org/B/BU/BUGEAUD_DE_LA_PICONNERIE.htm (last visited Nov. 6, 2003). 
court. ${ }^{102}$ But it also reflected shifting patterns of both political and sexual liberation. In the middle of the nineteenth century, the claims of the free press became more insistent, and public morality became less strait-laced. Both developments created privacy problems for French law.

Already in the $1850 \mathrm{~s}$, some famous cases affirmed the core privacy right that would come to be known in French law as the "right to one's image." These first cases involved deathbed photographs - in two cases, deathbed photographs of celebrity beauties, and in one case the deathbed photograph of a kind of Mother-Teresa-type street missionary. ${ }^{103}$ But it was the following decades that saw the most striking developments-in particular, developments that involved the comparatively unbuttoned sexual atmosphere of later-nineteenth-century Paris. Sexual license and the law of privacy have always gone hand in hand; and France had been famous for its relatively loose morals since at least the eighteenth century, the aristocratic age of Watteau, Boucher, and Fragonard. This tradition revived in the mid-nineteenth century, the age of the cancan, and it gave rise to numerous "privacy" issues, as cultures of sexual liberation tend to do. Especially beginning in the gay years of the 1860s, "right to one's image" cases began to multiply.

A particularly famous 1867 case involved Alexandre Dumas père, the author of The Three Musketeers-itself an important document of nineteenth-century French dueling culture. Dumas père, then well on in years, became involved in a love affair with Adah Isaacs Menken, a thirty-two-year-old Texas actress and horsewoman, famous for appearing on stage dressed only in a body stocking. Obviously reveling in their rejection of bourgeois values, the scandalous Menken and Dumas posed (together with Menken's mother!) for several more or less salacious photographs. Some of them showed Menken in her underwear. Others showed her in amorous poses with Dumas, who was not wearing a jacket. Dumas, whether through inadvertence or sheer glorious indifference, did not enter into any express agreement with the photographer about the rights to publish the photos. Seizing his chance, the photographer tried to register his copyright in what were highly marketable images. In responding to the photographer's application, the copyright officials were not entirely without delicacy: They forbade him to display the photos showing Miss Menken in

102. E.g., 1 CAUCHY, supra note 98 , at 3,18 .

103. Sergent c. Defonds, Trib. civ. Seine, Nov. 11, 1859, 6 ANNALES DE LA PROPRIÉTÉ INDUSTRIEL LE ARTISTIQUE ET LiTTÉRAIRE [A.P.I.A.L.] 168 (1860); Félix c. O'Connell, Trib. civ. S[e]ine, June 16, 1858, 4 A.P.I.A.L. 250 (1858); Soeur Mélanie c. Fougère, Ord. de Référé, Apr. $11,1855,6$ A.P.I.A.L. 167 (1860). The beauties were Rachel, a famous tragic actress, and a certain Mademoiselle Sergent, who, to judge by the opinion, lived something of a loose but exciting life. The missionary was Soeur Rosalie. The graves of both Rachel and Soeur Rosalie are still visited today by Paris cemetery tourists. For general discussion, see Dumas c. Jacquet, Trib. civ. Seine, June 20, 1884, 33 A.P.I.A.L. 280, 286 (1888) (comment Vaunois). 
her underwear. ${ }^{104}$ With regard to the other photos, though, they gave the photographer free rein, and he marketed them widely, causing an international scandal.

Dumas, perhaps under pressure from his family, sued. ${ }^{105}$ But could any objection be raised in law? This was a difficult question in the $1860 \mathrm{~s}$. The photographer had a property right, the copyright in the photographs. Indeed, Dumas admitted in open court that he had sold the rights. ${ }^{106}$ This was the mid-nineteenth century, and property rights were generally regarded as something close to sacred in the legal cosmos of the day. ${ }^{107}$ Nevertheless, adventurous legal thinkers were beginning to challenge the sanctity of private property, ${ }^{108}$ and the Dumas court did the same. If Dumas did not have the property right, was there any countervailing "right" that he could claim? In a seminal decision, the Paris appeals court answered that question by holding that he had a new kind of "right to privacy," which qualified the absolute claims of the law of property. The court adopted Royer-Collard's famous 1819 language about "private life": Even if a person had tacitly consented to the publication of embarrassing photos, that person must retain the right to withdraw his consent. "The very publication" of such photos could put such a person on notice "that he had forgotten to take care for his dignity, and remind him that private life must be walled off in the interest of individuals, and often in the interest of good morals as well."109 The court accordingly rendered the photographer's property right effectively meaningless, ordering him to sell all rights in the photographs to Dumas.

Privacy, the court had effectively held, must sometimes be allowed to trump property, at least where lascivious images were involved: One's privacy, like other aspects of one's honor, was not a market commodity that could simply be definitively sold. Any sale by a person who had momentarily "forgotten his dignity" had to remain effectively voidable. In subsequent cases, involving some of the most famous artists of the day, this sort of thinking began to gel into a developing right to one's image-an important part of the French law of privacy, understood as an aspect of the

104. Dumas c. Liébert, CA Paris, May 25, 1867, 13 A.P.I.A.L. 247 (1867).

105. Such is the account, at least, of WOLF MANKOWITZ, MAZEPPA: THE LIVES, LOVES AND LEGENDS OF ADAH ISAACS MENKEN 177 (1982). For a somewhat different account, see BERNARD FALK, THE NAKED LADY OR STORM OVER ADAH 199-203 (1934).

106. See MANKOWITZ, supra note 105, at 177.

107. For a classic account, see 1 JuSTUS WILHELM HedemanN, DIE ForTSCHRITTE DES ZIVILRECHTS IM XIX JAHRHUNDERT 14-26 (1910); and 2 id. at 1-79.

108. For examples of this developing attitude, and the rebellion against it in this period, see Paolo Grossi, an alternative to Private Property: Collective Property in the JUdiCIAL CONSCIOUSNESS OF THE NINETEENTH CENTURY (Lydia G. Cochrane trans., 1981).

109. Dumas, 13 A.P.I.A.L. at 250 ("[L]'effet même de la publication . . . que si la vie privée doit être murée dans l'intérêt des individus, elle doit l'être aussi souvent dans l'intérêt des mours ...." (emphasis added)). 
law of artistic and intellectual property. ${ }^{110}$ One memorable 1877 dispute, for example, involved Jean-Auguste-Dominique Ingres, the brilliant history painter and portraitist. The cult of nude figure drawing was at its height in mid-nineteenth-century France, and Ingres frequently found it difficult to capture the ladies who sat for him unless he had first sketched them nude. Of course his society clients would not agree to sit nude themselves, so Ingres hired models with appropriate body types, and did nude sketches to which he added the recognizable heads of his clients. It was a consequence of this louche artistic practice that a nude sketch of one of his sitters, Madame Moitessier, appeared among his effects at his death in 1868. When his executor tried to sell the drawing, Monsieur Moitessier sued. The court hearing the case, like the Dumas court, assigned the property right in the sketch to Ingres's successors. But, again like the Dumas court, the court held that Monsieur Moitessier had a privacy right, a right to his wife's "image," which served to limit the artist's property right. The court held that

property itself recognizes limits established not only by positive law, but also by social norms [les convenances sociales]; that the first of these norms consists in the respect owed to the inviolability of the domestic hearth; that that inviolability would be offended if the image of the mere de famille could be surrendered to the publicity of a banal public auction. ${ }^{11}$

The court accordingly ordered the dealer in possession of the sketch to sell it to Monsieur Moitessier. The same basic analysis was confirmed in yet further high-profile cases over the following decades, which established the principle that we have a "sacred and inalienable right over ourselves, and consequently over the reproduction of our image."112 The most famous of these was the 1900 lawsuit between James Whistler and the Baronet

110. For codification of this principle, see CODE DE LA PROPRIÉTÉ INTELLECTUELLE [C. PROP. INTELL.] art. L. 122-4 (Pierre Sirinelli et al. eds., 3d ed. 2002), as well as the extensive reportage in the Annales de la Propriété Industrielle Artistique et Littéraire. See, e.g., supra notes 103-104.

111. Moitessier c. Féral, Trib. civ. Seine, Dec. 5, 1877, 23 A.P.I.A.L. 92, 95 (1878) ("Que la propriété elle-même reconnait des bornes établies non-seulement par la loi positive, mais par les convenances sociales; que la première de ces convenances consiste dans le respect dû à l'inviolabilité du foyer domestique; que cette inviolabilité serait atteinte si l'image de la mère de famille pouvait être livrée à la publicité d'une exposition d'enchères banales ...."). For further details of the case, see Gary Tinterow, Madame Paul-Sigisbert Moitessier, née Marie ClotildeInés de Foucauld, in PORTRAITS BY INGRES: IMAGE OF AN EPOCH 426, 441 (Gary Tinterow \& Philip Conisbee eds., 1999); and Hans Naef, New Material on Ingres's Portraits of Mme Moitessier, BURLINGTON MAG., Mar. 1969, at 149.

112. Dumas c. Jacquet, Trib. civ. Seine, June 20, 1884, 33 A.P.I.A.L. 280, 286 (1888) (comment Vaunois) ("[D]roit sacré et inalienable que nous avons sur nous-mêmes et, par suite, sur la reproduction de notre figure ...." (internal quotation marks omitted)). 
Eden, which Whistler himself chronicled in his little screed The Baronet and the Butterfly. ${ }^{113}$

In part, French privacy law was thus the product of the culture of the Paris art world, with its nude models, defiant immoralism, and large artistic egos. The cases that grew out of that world generally concluded that there was a right to one's "image" that was distinct from, and in tension with, rights of property. But that was only one of the strains in the making of French privacy law. The other had to do with the free press, and it reflected exactly the same anxieties that had accompanied press liberalization in 1791 and 1819.

Indeed, it was in the tradition of uneasiness about the free press that privacy received its first formal statutory protection of the nineteenth century, in 1868, during the waning years of Napoleon III's imperial regime. Over the course of the 1860 s, the period of the so-called "Liberal Empire," Napoleon III granted increasing civil rights in France. This included the creation of a new press policy in 1868, which, with some limitations, allowed effective freedom of the press. The French press, meanwhile, had been experiencing a small renaissance of critical and satirical reportage, as well as a renaissance of French caricature in the work of artists like Honoré Daumier. ${ }^{114}$ Attitudes had not changed since 1819 , though, and the new law aimed to guarantee that freedom of the press would not open the door to insulting intrusions into the lives of respectable people. Thus, it carefully provided that, though the press was in principle free, every publication in a periodical of "a fact of private life" was a criminal offense-a punishable contravention, just as other insults were contraventions. ${ }^{115}$ An interpretive circular of the Ministry of Justice added that while there was of course room for criticism of artists and other public figures, even the latter were (as they would continue to be) protected against "defamation and insult." 116 Concerns about the care of one's dignity thus continued to shadow press liberalization, just as they had in 1791. ${ }^{17}$

With the fall of Napoleon III, the climate certainly changed, and when the Third Republic turned to the regulation of the press, in 1881 , its new

113. Eden c. Whistler, Cass. civ., Mar. 14, 1900, D.P. 1900, I, 497, 500; EDEN VERSUS WHISTLER: THE BARONET \& THE BUTTERFLY (Notable Trials Library spec. ed. 1997) (1899); see also RIGAUX, supra note 42, at 157-59, 288.

114. See generally Roger BELlet, PRESSE ET JOURNALISME SOUS LE SECOND EMPIRE 18-24 (1967) (surveying press activity under the Second Empire).

115. "Toute publication dans un écrit périodique relative à un fait de la vie privée constitue une contravention punie d'une amende de cinq cent francs. La poursuite ne pourra être exercée que sur la plainte de la partie intéressée." Loi Relative à la Presse (May 11, 1868), in H.F. RJVIĖRE ET AL., CODES FRANÇAIS ET LOIS USUELLES app. 2 at 19, 20 (1889). For the treatment of insults as contraventions, see Whitman, supra note 42, at 1349.

116. Loi Relative à la Presse, supra note 115 , app. 2 at 20 n.3(b).

117. See supra text accompanying notes 89-94. 
statute said nothing about "privacy" as such. ${ }^{118}$ Nevertheless, courts continued to insist on the sacred character of "la vie privee"-for example, in forbidding a writer to base a novel on events revealed in the course of a criminal trial. ${ }^{119}$ All told, France was, by the 1870 s and 1880 s, the home of a very visible law of the protection of privacy. ${ }^{120}$ The reigning French view was captured by a characteristic account that appeared in 1888, two years before the publication of Warren and Brandeis's Right to Privacy. In that year, Émile Beaussire, an eminent legal philosopher of the day, summarized several decades of French development in the following way: The right to privacy was to be ranked among the rights to honor more broadly. This of course raised doubts about its place in the law. For understandably, Beaussire wrote, people viewed their "honor" as something that should be preserved through dueling, not through law: "When my honor is attacked, I gain nothing by filing suit against my calumniators." ${ }^{121}$ Nevertheless, in the modern world, even persons of honor had to have recourse to the law, and the law had to occupy itself with persons of honor. This was the right context for understanding the right to privacy, for violations of privacy involved nothing less than the revelation of "infamous secrets," which could destroy the honor of such persons as a respected "père de famille."122 And outside the most exceptional circumstances, the law could not allow such violations:

$[P]$ rivate honor, whatever its value per se and whatever its source, must be protected from all offenses. People have certainly mocked the excesses of the maxim "private life must be walled off."... [Nevertheless,] [t]he prying and insults of the world may be ... more or less innocent or more or less culpable: no matter what, they violate the law when they tend to destroy, through public revelation...honor [considération] justly or unjustly acquired .... ${ }^{123}$

118. Monique Contamine-Raynaud, Le secret de la vie privée, in L'INFORMATION EN DROIT PRIVÉ 406 (Yvon Loussouarn \& Paul Lagarde eds., 1978). Contemporary commentary did worry over protecting the private life of the President of the Republic, though. See J. GAHIER, LA DifFamation ET LA LoI DU 29 JUILlet 1881, at 80 (Paris, Librairie Générale de Jurisprudence 1893).

119. Le Figaro c. Chaperon, CA Paris, 4e ch., Dec. 2, 1897, 45 A.P.I.A.L. 61 (1899).

120. Not all French commentators approved of this development. One leading scholar, for example, argued that French law was beginning to entrench too drastically on the work of artists. The "right to one's image," he thought, should not extend beyond the traditional protection against "insult and defamation." VAUNOIS, supra note 96 , at 6.

121. ÉMILE BEAUSSIRE, LES PRINCIPES DU DROIT 369 (Félix Alcan ed., Paris, Ancienne Librairie Germer Baillière 1888) ("Quand mon honneur est attaqué, je ne gagne rien à poursuivre en justice mes calomniateurs.").

122. Id. at 372-73.

123. Id. at 377-78 ("[L]'honneur privé, quelle qu'en soit la valeur en lui-même et dans son origine, doit être à l'abri de toute atteinte. On a pu railler ce qu'il y'a d'excessif dans la maxime 
Similar accounts of the right to privacy as a right to "honor" made their way into other textbook accounts by the end of the nineteenth century as well, ${ }^{124}$ and the importance of the protection of "honorable" privacy was something close to orthodoxy in France by the 1890s.

\section{THE RISE OF GERMAN PRIVACY LAW}

In Germany, similar developments were underway by the late nineteenth century. The world of the developing German law of privacy was not the overheated world of Paris high art, though, with its nude models and lascivious photos. Instead, it was the heady world of the German philosophy of free will. Moreover, German privacy law developed more slowly than French law, not really establishing itself before the middle of the twentieth century. And when German privacy law did establish itself, it was in connection with the painful experience of Nazism.

The German tradition of privacy protections is perhaps easiest to understand if we emphasize one point: German privacy law grew in large part out of an effort to create a richer German alternative to the ideas of liberty that grew up west of the Rhine, and especially to English ideas of liberty. The protection of privacy in the German tradition is regarded as an aspect of the protection of one of the most baffling of German juristic creations: "personality." Personality is a characteristically dense German concept, with roots in the philosophies of Kant, Humboldt, and Hegel. Standard texts describe this concept in the daunting language of continental philosophy. As one recent author explains, the German law of personality is a law of freedom - the law of the Inner Space, "“in which... [humans] develop freely and self-responsibly their personalities.",125 Standard texts also lodge the concept in the drama of modern German history: This law of freedom, they tell us, has especially flourished since the 1950s, when Germans applied the lessons they had learned from the Nazi disaster. ${ }^{126}$ Clearly "personality" is somehow central to German legal culture. But the concept is likely to seem elusive to most readers. What is the "Inner

que 'la vie privée doit être murée.' . . [Nevertheless,] [l]es curiosités et les médisances du nonde peuvent être . . . plus ou moins innocentes ou plus ou moin blâmables: elles violent le droit quand elles tendent à détruire par une révélvation publique ... une considération justement ou même injustement acquise ...."). For Beaussire's identification of "honneur" and "considération," see id. at 377.

124. E.g., 1 A. Boistel, Cours DE PhILOSOPHIE du DROIT 243-47 (A. Fontemoing ed., Paris, Ancienne Librairie Thorin et Fils 1899).

125. EBERLE, supra note 42, at 85 (quoting The Microcensus Case, Entscheidungen des Bundesverfassungsgerichts [BVerfGE] [Federal Constitutional Court] 27, I (7) (F.R.G.)).

126. Id. at 7. For a standard postwar German account, see Ernst von Caemmerer, Wandlungen des Deliktsrechts, in 2 HUNDERT JAHRE DEUTSCHES RECHTSLEBEN 49, 104-06 (Ernst von Caemmerer et al. eds., 1960). 
Space"? How does guaranteeing the freedom of the "Inner Space" represent an antidote to Nazism?

To get a firmer handle on these difficult ideas, we must dig deeper into German intellectual history, and even into German theology. Personality is indeed a concept that Germans have often invoked where Americans would invoke liberty, and like liberty it does involve a kind of freedom. But from the beginning it was never quite the same as American freedom. Where Americans often think of "freedom" as opposed primarily to tyranny, nineteenth-century Germans often thought of "freedom" as opposed primarily to determinism. To be free was, in the first instance, not to be free from government control, nor to be free to engage in market transactions. Instead, to be free was to exercise free will, and the defining characteristic of creatures with free will was that they were unpredictably individual, creatures whom no science of mechanics or biology could ever capture in their full richness. For Germans who thought of things in this way, the purpose of "freedom" was to allow each individual fully to realize his potential as an individual: to give full expression to his peculiar capacities and powers.

This idea of "free" self-realization is as old as Leibniz, or even Erasmus. Indeed, its sources lie unmistakably in Christian Humanism. ${ }^{127}$ But in its modern form, it is an idea that was especially championed by Wilhelm von Humboldt in the early nineteenth century. ${ }^{128}$ The early nineteenth century was a period when Germans were struggling with the economic liberalism of Adam Smith, trying to learn the lessons of Smith while preserving some role for a managed economy as well as for ideals of freedom that were not defined by the market. ${ }^{129}$ For writers of the period like Humboldt, it seemed essential to insist that human flourishing required the pursuit of individual fulfillment in forms the market could not provide. The paradigmatic free actor, for such German philosophers, was commonly the artist more than the consumer. The German philosophical tradition on the subject of freedom was thus close in spirit to the German tradition of socalled "national" economics, a school critical of free trade and in many ways of the free market more broadly. That does not mean that German philosophers (or German economists) did not believe in the freedom to buy and sell, of course. Nor does it mean that there have never been English or American writers who have found the German approach wise and

127. For an account, see CORNELIS AUGUSTIJN, ERASMUS EN DE REFORMATIE 13-16 (1962).

128. See LEONARD KRIEGER, THE GERMAN IDEA OF FREEDOM: History OF A POLITICAL TRADITION 166-69 (1957).

129. See, e.g., LAURENCE Dickey, Hegel: Religion, ECONOMics, AND the Politics of SPIRIT, 1770-1807, at 194-97 (1987). 
beautiful. ${ }^{130}$ It means only that the German tradition always put less of an emphasis on consumer sovereignty, and more of an emphasis on unfettered creation, than the Anglo-American tradition did-and most especially on the unfettered creation of the self, on the fashioning of one's image and the realization of one's potentialities. This approach to the problem of freedom formed a fundamental part of what Leonard Krieger, writing in the wake of the Nazi experience, famously called "The German Idea of Freedom": ${ }^{131}$ an idea different from Anglo-American ideas of liberty-an idea focused much more on inward self-realization, and consequently much more open to the exercise of state power and regulation of the market.

Now these are philosophical ideas that are both vague and grandiose, and they are not obviously easy to translate into law. Certainly, they do not seem as easy to translate into law as the ideas of an Adam Smith. Nevertheless, they were embraced by German jurists of the second half of the nineteenth century, and particularly of the $1880 \mathrm{~s}$. This was the period when German public policy began to turn away from Smithian laissez-faire ideas, endorsing social insurance, cartelization, and protectionist policies. It was also the period when German philosophers turned strongly toward neoKantianism, a philosophical style fascinated with the tension between free will and determinism. It was during this same period that German lawyers began to turn away from seemingly crass Western ideas of personal liberty, endorsing the theory of personality as the true theory of freedom. Inspired by both Kant and Hegel, a number of leading legal thinkers set out to create a German law that would match the German philosophy of personality in depth and subtlety. In particular, they developed a German tradition that treated the protection of privacy simply as one aspect of the protection of personality more broadly: Privacy, for Germans, became one part of "free self-realization."

Like their French predecessors of several decades earlier, German jurists in and after the 1880 s perceived their problem as a problem of honor, to be dealt with through the law of insult, in coordination with the law of artistic property. German society, like French society of the same period, was strongly attached to norms of respectability and honor, notably as asserted through dueling. It was also a society in which the law of insult played a correspondingly large role in legal thinking. ${ }^{132}$ But the French way of talking about the problem was not very satisfactory to German scholars. When French authors like Royer-Collard or Beaussire spoke of "insults," they based their arguments on clumsily drafted modern statutes and vague

130. For a leading recent example of this tradition in the Anglo-American world, which could also be said to include Ralph Waldo Emerson and John Stuart Mill, see MARGARET JANE RADIN, CONTESTED COMMODITIES 54-60 (1996).

131. KRIEGER, supra note 128.

132. See Whitman, supra note 42 , at $1313-32$. 
"social norms." 33 German scholars preferred a more solid juristic foundation, with citations to authoritative ancient texts and explorations of basic problems in legal philosophy. Rather than talking about ill-defined social norms, German jurists accordingly embarked on an impressive reinterpretation of one of the most confusing bodies of traditional law: the ancient Roman law of insult, which they combined with the law of artistic property to create a new body of personality law. This German reinterpretation of the ancient law of insult is one of the finest examples of nineteenth-century juristic virtuosity, and one of the most famous. It deserves to be described, even if only briefly, not least because it exercised an important influence on American scholars like Warren and Brandeis.

Let us then follow nineteenth-century German reasoning. The ancient Roman law of insult was by no means easy to use as a basis for a modern law of personality. The ancient Roman texts were extremely muddy. In very early Roman law, which produced a cryptic statute on the matter, the law of insult-injuria-seemed to cover certain injuries to a person's possessions. In addition, there were early Roman sanctions against casting spells, engaging in certain now-mysterious forms of public insults, and inflicting bodily injury. ${ }^{134}$ Very gradually, over the long course of Roman history, this early grabbag of legal prohibitions also came to cover various kinds of disrespectful and insulting speech and treatment. In particular, as the confusing texts of the Digest of Justinian seem to show, it came to protect respectable women against lewd comments, and to guarantee to a certain extent that low-status persons would show proper deference to their betters, as well as that high-status persons would not insult their inferiors. ${ }^{135}$ A variety of other interferences with the rights of other persons also apparently came to be considered "injuria." 136 Nowhere did the Roman jurists explain how they thought that physical "injuries" to persons and their possessions were related to verbal "injuries" directed at respectable women by mashers and the like, or give any account of what social purposes, if any, the Roman law of injuries was thought to serve.

This was not easy stuff to work with, but German scholars went to work with a will. In particular, they worked in the Hegelian tradition. Hegelian legal historians brought a characteristic approach to the understanding of legal evolution-an approach founded on Hegel's account of the history of punishment. According to the Hegelian view, the history of punishment was one in which the primitive talionic rule of "eye for an eye,

133. See supra Part IV.

134. For a summary of these prohibitions, see RÖMISCHES RECHT $\S 131$ (Heinrich Honsell et al. eds., 4th ed. 1987).

135. For a convenient collection of translated texts, see BRUCE W. FRIER, A CASEBOOK ON THE ROMAN LAW OF DELICT 3-6, 177-200 (1989).

136. See RUDOLPH VON JHERING, Rechtsschutz gegen injuriöse Rechtsverletzungen, in 3 GESAMMELTE AUFSÄTZE 233, 234-35 (Jena, Fischer 1886). 
tooth for a tooth," had gradually given way to more sophisticated concepts of proportionality. This was an evolution, as Hegelians saw it, in which a naive view of the world obsessed with things-eyes and teeth-had gradually evolved into a view of the world capable of grasping larger immaterial values. $^{137}$

The creators of the German law of "personality" interpreted the development of the ancient Roman law of insult in the same way-as an evolution of the "spirit" of Roman law, as Rudolf von Jhering, the most brilliant of German law professors, called it, ${ }^{138}$ from the material to the immaterial. The argument ran as follows: Honor had always been at stake in the law of insult, even in the earliest periods. At first, the Romans, still obsessed with things, had thought that the law could only vindicate monetizable rights, mere material rights. But as sensibilities about honor grew richer and deeper, these early legal protections gradually ripened, until the law grew to cover all aspects of honor, protecting also against verbal insults and other shows of disrespect. ${ }^{139}$ The evolution of the law of honor, like the evolution of the law of punishment, was thus an evolution in the "spirit of the times"- - one in which primitive protections for merely monetizable interests had gradually matured into sophisticated protections for "noneconomic" interests. ${ }^{140}$ That slow evolution, from the material to the immaterial, was moreover continuing in the modern world: The modern world was now producing what Jhering called, in a famous 1885 article, the law of "insulting tortious injuries." In particular, modern protections were now evolving beyond protections against immaterial verbal insults, to include the protection of such immaterial goods as one's name ${ }^{141}$ and one's photographed image, ${ }^{142}$ one's control of one's correspondence, ${ }^{143}$ as well as access to modern amenities such as the telegraph and the tram. ${ }^{144}$

Jhering was one of a number of German scholars to make this sort of argument, some relying on ancient Roman law, some drawing on Germanic sources. ${ }^{145}$ This Hegelianized law of insult was one main strand in the new German law of personality. The other was the law of Urheberrecht, creators' rights. The rights of an artistic or intellectual creator, in German law, were partly rights of copyright. But they also were beginning to extend

137. See James Q. Whitman, At the Origins of Law and the State: Supervision of Violence, Mutilation of Bodies, or Setting of Prices?, 71 CHI.-KENT L. REV. 41, 58-68 (1995).

138. RUDOLPH VON JHERING, GEIST DES RÖMISCHEN RECHTS AUF DEN VERSCHIEDENEN STUFEN SEINER ENTWICKLUNG (Leipzig, Breitkopf und Härtel 5th ed. 1891).

139. JHERING, supra note 136, at 235 .

140. Id. at 236.

141. Id at $390-96$.

142. Id. at 383-84, 389-90.

143. Id at $385-89$.

144. Id. at 344-45.

145. For a parallel effort focused more on Germanic sources, see 3 OTTO VON GIERKE, DEUTSCHES PRIVATRECHT 958-63 (1917). 
beyond mere copyright to include a broader right to control the use of one's work, in the name of protecting one's reputation as an artist-what in continental law is today called "droit moral de l'auteur." "46 For German scholars who thought of "personality" as the right to free self-creation, the law of artistic and intellectual property was a natural source, to be exploited alongside the law of insult. ${ }^{147}$ After all, personality was precisely about self-creation. And of course, protection of the creative rights of the artist, a nineteenth-century innovation, was a classic example of the new modern sensitivity to immaterial interests.

The law of insult, united with the law of artistic creation, thus made for what seemed to Germans a solid foundation for a law of personality. The idea that personality was really about an amalgam of personal honor and artists' rights was popularized beginning in the late 1870 s by an influential writer named Karl Gareis. ${ }^{148}$ Related approaches were developed in particular by the most deeply learned and intellectually adventurous of turn-of-the-century legal thinkers, Josef Kohler. ${ }^{149}$ Some important cases came into this German line of thinking as well: In particular, there was a case that prohibited the distribution of photographs of Otto von Bismarck on his deathbed. ${ }^{150}$ As always in the continental tradition, the hunger of the press for images of highly placed persons drove the law onward.

These were very influential ideas in the developing German social order of the late nineteenth century. By the early twentieth century, German law had incorporated a wide variety of personality rights into its statutory

146. For codification of this concept, see C. PROP. INTELL. art. 121-1 (Fr.). For discussion of this concept, see Jill R. Applebaum, Comment, The Visual Artists Rights Act of 1990: An Analysis Based on the French Droit Moral, 8 AM. U. J. INT'L L. \& PoL'Y 183 (1992); and Russell J. DaSilva, Droit Moral and the Amoral Copyright: A Comparison of Artists' Rights in France and the United States, 28 BULL. COPYRIGHT SOC'Y 1 (1980).

147. See 1 VON GIERKE, supra note 145 , at 748-848; id. at 764 ("Das Urheberrecht ist . . in seinem ganzen Umfange als ein aus geistiger Schöpfung fliessendes Persönlichkeitsrecht zu konstruiren." (emphasis added)). Otto von Gierke drew on J. KOHLER, DAS AUTORRECHT: EINE ZIVILISTISCHE ABHANDLUNG (Jena, Fischer 1880) [hereinafter KOHLER, DAS AUTORRECHT]. Kohler was, however, critical of Gierke's approach. See J. Kohler, Zur Konstruktion des Urheberrechts, 10 ARCHIV FÜR BÜRGERLICHES RECHT 241, 246-58 (1895). Moreover, there was much dispute during the nineteenth century over whether rights in works of art should be understood as an aspect of the protection of personality or not. For a rapid survey of theories predating the triumph of the "personality" analysis, see OSTERRIETH, supra note 80, at 5-7.

148. For more on the writing and role of Gareis, see DIETER LEUZE, DIE ENTWICKLUNG DES PERSÖNLICHKEITSRECHTS IM XIX JAHRHUNDERT 93-103 (1962).

149. See KoHler, DAS AUTORRECHT, supra note 147, at 123-59; id. at 126 (using the term "Persönlichkeit"). For more on Kohler, see LEUZE, supra note 148, at 103-11. In his mature reflections, Kohler in effect rejected both Roman and Germanic approaches in ways that deserve more discussion than I can give them here. See, e.g., KOHLER, supra note 42.

150. The famous Bismarck case was preceded by a couple of other photography cases, involving a woman in a bathing suit and a photograph used to advertise a hair dye. But it was the Bismarck matter that really caught the public imagination in Germany. See OSTERRIETH, supra note 80, at 161 (describing the origins of the protections for one's image contained in $\$ \$ 22-24$ KUG). Osterrieth also mentions protections for portraits and portrait busts-but just for those who ordered the work in question, not for those portrayed. 
schemes. The scandal over Bismarck's deathbed photos led, in 1907, to the introduction of statutory protections for one's image, as part of a larger scheme regulating rights in works of art. ${ }^{151}$ Meanwhile, the German Civil Code, which went into force in 1900, included protections against the appropriation of one's name ${ }^{152}$ and the impairment of one's credit, ${ }^{153}$ alongside protections for life, body, health, and liberty. ${ }^{154}$ The 1909 law on unfair competition included a characteristically German provision protecting enterprises against untrue statements that harmed their operations or their credit, ${ }^{155}$ and the Bismarck-era law on freedom of the press granted a right to respond. ${ }^{156}$ Perhaps most importantly, the Criminal Code included a prohibition on insults. ${ }^{157}$ All of this added up to protections that were hardly insignificant by the eve of World War I. The Weimar era saw a number of further important cases, particularly involving members of the formerly imperial Hohenzollern family and like personages. ${ }^{158}$

In short, there were plenty of "personality" protections in German law by the early part of the twentieth century. Nevertheless, the Civil Code itself, which went into force in 1900, did not endorse an unbounded right of personality ${ }^{159}$ - much to the dismay of many legal scholars. Indeed, it is an important part of German legal lore that personality was neglected in the Civil Code. This peculiarly German form of freedom, German lore tells us, was not embraced by the Code, which instead endorsed crassly marketoriented values. ${ }^{160}$ The German literature routinely declares that personality was only fully protected in the 1950s, as a consequence of the new commitment to freedom and dignity that took hold in the wake of Nazism.

151. Failure to protect the image, the official government draft for this law explained, would not do justice to "the respect which is owed to the personality." Regierungsvorlage $\S \S 22-24$ KUG, reprinted in OSTERRIETH, supra note 80, at 161 . The image needed to be protected in a way that would "leave freedom of movement for the respectable press, without leaving justifiable private interests without protection." OSTERRIETH, supra note 80, at 163.

152. $§ 12$ BGB.

153. Id. $\S 824$, para. 1 .

154. Id. $\S 823$, para. 1 .

155. $\S 14$, para. 1 GESETZ GEGEN DEN UNLAUTEREN WETTBEWERB.

156. $\$ 11$, paras. 1-3 REICHSPRESSEGESETZ.

157. $\S 185$ STRAFGESETZBUCH. For a view of these provisions as forerunners of developed German Persönlichkeitsrecht, see von Caemmerer, supra note 126, at 102-03.

158. For a summary of these cases, see ALEXANDER ELSTER, URHEBER-UND ERFINDERWARENZEICHEN-UND WETTBEWERBSRECHT $191-92$ (2d ed. 1928). Royalty were not the only ones protected, though. For a case involving a typist, from whose life episodes were lifted by a novelist, see Nichtanerkennung des allgemeinen Persönlichkeitsrechts, 4 UFITA ARCHIV FÜR URHEBER-, FILM-, FUNK- UND THEATERRECHT 319, 319-23 (1931). One is tempted to think of this case as foreshadowing the social extension of protections during the Nazi period. In his account of the period, Stefan Gottwald emphasizes economic interests more than I do here. See GoTTWALD, supra note 83 , at 14-46.

159. The Civil Code was decisively so interpreted in Entscheidungen des Reichsgerichts in Zivilsachen 51, 373.

160. For a sensitive presentation of this position, see Helmut Coing, Zur Entwicklung des zivilrechtlichen Persönlichkeitsschutzes, 1958 JURISTENZEITUNG 558, 559. 
Indeed, the protection of personality is widely presented as the core institution of a German private law shaped by the reaction against Nazism - "one of the most essential achievements," as a standard textbook says, "of the post-war period."161

This is not, however, correct. With this we come to a delicate point, which I have touched on before and now must touch on again. Here, as elsewhere, contemporary German institutions of dignity have a Nazi history. In point of fact, the Nazis too were committed to the protection of personality. ${ }^{162}$ This German form of freedom was one that appealed to the Nazis just as it appealed to the later makers of the twentieth-century social welfare state. The story is entirely typical of the history I have recounted elsewhere. ${ }^{163}$ The Nazi regime, like other fascist regimes, made great efforts to proclaim the importance of "honor"-and most especially the importance of the honor of low-status persons, as long as they were racially German. This led the regime to insist on norms of respect for workers in the workplace, and in everyday life as well. ${ }^{164}$ In just the same way, it led the regime to insist that all Germans, whatever their social station, had a right to the protection of their personality. Otto Palandt's standard commentary to the Civil Code explained it this way in the early 1940s:

The "right of personality" did not receive any definitive regulation in the Civil Code. Life, body, health, and freedom are protected through $\S 823 \mathrm{I}$, and so is the right to one's name .... A general right of personality is alien to the Civil Code. However, there is nothing in the Code that excludes it. National Socialist legal feeling [National-sozialistisches Rechtsempfinden] regards the Volk-comrade as a member of the Volk community, who fulfills the demands of his legal position in the service of the Volk community, and who as such has a claim that the legal position that has been conferred upon him be safeguarded and protected against attacks of any kind. In this sense, it can be said that the Volk-comrade has a general right of personality that ought to be recognized, one whose content extends beyond the above-mentioned personality interests

161. Claus Ahrens, Persönlichkeitsrecht UND FreiheIt Der MEDIENBERICHTERSTATTUNG 28 (2002). This commonplace view can now be found in almost any comparative law text. See, e.g., Ugo MatTei, Comparative LaW and ECONOMics 115-16 (1997). For a typical account of constitutional development after the war, see Hans D. Jarass, Die Entwicklung des allgemeinen Persönlichkeitsrechts in der Rechtsprechung des Bundesverfassungsgerichts, in RECHT DER PERSÖNLICHKEIT, supra note 76, at 89, 89-103.

162. This remains an unwritten chapter of German legal history, outside a brief but valuable discussion by Gottwald. See GoTTWALD, supra note 83 , at 47-58. Broadly speaking, Nazi writers tended to promise protection of the "Ehre" of ordinary Germans as a kind of exchange for their submission to the demands of the "folk community." See, e.g., JuSTUS WILHELM HEDEMANN, DAS VOLKSGESETZBUCH DER DEUTSCHEN: EIN BERICHT 37 (1941).

163. See WHITMAN, supra note 55, at 140-41; Whitman, supra note 42, at 1325-30; Whitman, supra note 60 , at 243-66.

164. Whitman, supra note 42 , at 1327-30; Whitman, supra note 60 , at 251-62. 
listed [in the Code], including in particular a right to join in the common labor of the community and a right to recognition, respect, and honor .... ${ }^{165}$

The draft Nazi Civil Code, never enacted, was even more assertive in its insistence on a universal German right to protection of personality. ${ }^{166}$ The Nazis presented themselves as protecting honor to its fullest extent, in return for the sacrifices demanded of the German Volk. Of course the insistence on honor for Germans was paired with an insistence on the dishonor of others- of persons who were "sick or foreign."167 Like all Nazi extensions of "honor" to the lower orders, this too belonged to the politics of the most vicious kind of exclusion. It is for that very reason that the rare historian who deigns even to talk about the Nazi period insists that there is no connection between Nazi ideas and the doctrines of the postwar period. ${ }^{168}$ Nevertheless, it is much too simple to dismiss the Nazi experience as a rejection of the traditions of German personality lawwhether we are talking about the history of legal doctrine, or about the social history of the law. As a matter of doctrine, the Nazis did endorse the general right of personality. As a matter of social history, the Nazis did guarantee, here as elsewhere, the claim to honor of low-status Germans. Ordinary Germans who would come to pride themselves on their "dignity" in the 1950s and 1960s were Germans who had been taught to pride themselves on their "honor" twenty years earlier.

The consequence, painful as it is to acknowledge, is that Nazi law directly prefigured the law of postwar Germany. By the 1950s and 1960s, to be sure, the standard commentary to the Civil Code was no longer grounding the "general right of personality" in "National Socialist legal feeling" and the requirement that the "Volk-comrade" work for and with the

165. From Palandt's original text:

Das "Recht der Persönlichkeit" hat im BGB keine abschließende Regelung gefunden. Leben, Körper, Gesundheit und Freiheit werden durch $\S 823$ I geschützt, ebenso das Namensrecht .... Ein allgemein[es] Persönlichkeitsrecht ist dem BGB fremd, RG 51, 376. Es ist aber durch keine Bestimmung ausgeschlossen. Nat[ional]soz[ialistisches] Rechtsempfinden sieht im Volksgenossen ein Glied der Volksgemeinschaft, das seine Rechtsstellung in deren Dienste auszfüllen hat und als solches Anspruch darauf hat, daß die ihm übertragene Rechtsstellung gewährleistet und gegen Angriffe jeder Art geschützt werde. In diesem Sinne dürfte heute ein allgemein[es] Persönlichkeitsrecht des Volksgenossen anzuerkennen sein (anders noch RG 113, 414, RAG, 33, 1911), dessen Inhalt über den Schutz der im Gesetz aufgeführten obengenannten Persönlichkeitsgüter hinausgeht, und insbes. ein Recht auf Mitarbeit im Rahmen der Gemeinschaft und auf Anerkennung, Achtung und Ehre ... .

Otto Palandt, Einführung vor $\S 1$, in BGB 4, 4 abs. 2 (Otto Palandt ed., 6th ed. 1944).

166. JUSTUS WILHEM HEDEMANN, VOLKSGESETZBUCH: GRUNDREGELN UND BUCH I, at 15-20(1942).

167. Heinz HermanN, Das allgemeine PersönliChKeitsrecht 35 (1935).

168. See, e.g., Hans Hattenhauer, "Person"-Zur Geschichte eines Begriffs, 22 JURISTISCHE SCHULUNG 410 (1982). 
community, as it had done in the 1940s. Instead it was (rather reluctantly) grounding it in the constitutional right to "free self-realization."169 But in both eras, the commentary talked a lot about "honor," 170 and the net result was that the German civil law acknowledged a "general personality right" in each. In point of fact, the protection of personality is not a product of postwar reforms, as German scholars must have known perfectly well during the 1950s. ${ }^{171}$ It has grown in tandem with the German social welfare state, and the downward social extension of a claim to honor, throughout the twentieth century.

Be that as it may, the protection of personality has especially flourished since the 1950s. The Basic Law of 1949 did embrace the German tradition of personality protection in its famous Article II, which guarantees that "[e]very person has the right to free development of his personality, insofar as he does not injure the rights of others." ${ }^{\prime 72}$ This was a forceful restatement of the German idea of freedom. In subsequent years, Article II has indeed come to stand at the foundation of the extensive German protection of privacy, among other personality interests. A number of cases of the $1950 \mathrm{~s}$ established the principle that the Civil Code had to be understood in light of this constitutional provision, as guaranteeing a right to the protection of personality. ${ }^{173}$ The postwar law of personality is now a central institution of German dignity in the (perhaps endangered) world of German market socialism.

\section{CONTEMPORARY CONTINENTAL LAW: PROTECTING THE AVERAGE PERSON'S PUBLIC IMAGE}

The old traditions described above have remained strong down to the present postwar day, in both Germany and France. Postwar developments were more tentative in France than in Germany. Protections for "privacy" were proclaimed by de Gaulle's government in exile shortly before D-Day,

169. The Palandt commentary was slow to accept the new doctrine on Persönlichkeitsschutz. Compare PALANDT Bürgerliches GeSETZBUCH $\S 823(6)$ (i), at 680 (Bernhard Danckelmann et al. eds., 16th ed. 1957) (finding that the new doctrine goes too far), with PALANDT BÜRGERLICHES GESETZBUCH $§ 823(6)(i)$, at 702 (Bernhard Danckelmann et al. eds., 28th ed. 1969) [hereinafter PALANDT BÜRGeRliCheS GESETzBUCH 1969] (adopting the "herrschende Meinung"- the accepted general opinion of scholars). For an important revisionist account of this period, arguing that the rise of the new doctrine was intended to protect ex-Nazis, see GoTTWALD, supra note 83 , at 59-124.

170. Palandt Bürgerliches Gesetzbuch 1969, supra note $169, \S 823(6)(\mathrm{i})$, at 702 ; Palandt, supra note 165 , at 4 .

171. Palandt himself, it should be noted, died in 1951. For a brief biography, see Klaus W. Slapnicar, Palandts langer Schatten: Biographisches über einen bekannten Fremden, http://www.vfh-hessen.de/ftp/Spectrum/2003-1-Palandt-Slapnicar.pdf (last visited Nov. 3, 2003).

172. GRUNDGESETZ [Constitution] art. 2, para. 1.

173. For a discussion of some of these cases in English, see EBERLE, supra note 42, at 25-35, 62-72, 98-99. 
presumably in the effort to win over former collaborators. ${ }^{174}$ Nevertheless, lasting change had to wait until 1970, when the Civil Code was amended to introduce new protections. ${ }^{175}$ Still, today protections for privacy are a proud part of the law in both countries-and in both, they have retained much of their nineteenth-century coloration. ${ }^{176}$ To be sure, the law of privacy in both countries is today regarded as distinct from the law of insult. ${ }^{177}$ Nevertheless, traditional nineteenth-century values, with their honororiented, suspicious attitude toward the free press and the free market, have continued to make themselves felt, even in a world in which the privacy of ordinary folks is vigorously protected.

The continental chariness about the free market shows, for example, in the treatment of consumer credit reporting and other consumer data. Credit reporting is an especially revealing example. Here the basic continental rules grow out of longstanding continental traditions. Historically, as a matter of etiquette, one's financial affairs were very much one's own affairs. One did not talk about money matters unless absolutely necessary: Indeed, money, as a standard etiquette guide will tell you, was simply "a taboo subject" among respectable people. ${ }^{178}$ The only persons whose finances were routinely revealed to the public were insolvents and bankrupts. That attitude has had a marked influence on European privacy law-most notably in the traditional French rule that made it a per se violation of privacy rights to reveal another person's salary. ${ }^{179}$ (Indeed, a French text on the law of privacy will still casually list "health, love, sex and earnings" as the areas of life self-evidently in need of privacy protections.) $)^{180}$

The same attitude has had an influence on the continental law of credit reporting. In France in particular, consumer credit reports are provided only by official sources, and they are provided only in the case of persons experiencing serious financial difficulty. They offer, as it were, only a watch list of persons who are proven credit risks. Anything else, to the French mind, would represent an intrusion into financial privacy. ${ }^{181}$ One's

174. Ordinance of May 6, 1944, J.O., May 20, 1944, p. 418; Gaz. Pal. 1944, 2, pan. jurispr. 292 (amending Law No. 637 of July 29, 1881, J.O., July 30, 1881, p. 125; D.P. 1881, IV, p. 65). For the limited impact on postwar law, see the discussion of Robert Badinter, Le droit au respect de la vie privée, JCP 1968 no.2136. Nevertheless, it is striking how infrequently this ordonnance is mentioned in the literature.

175. CODE CIVIL [C. CIV.] art. 9.

176. For the continuing vigor of the law of insult in France, see de Lamberterie \& Strubel, supra note 44 , at 356 .

177. BERTRAND, supra note 10 , at 17-18.

178. LE BRAS, supra note 16 , at 66.

179. This rule has been shaken somewhat in recent years. See BEIGNIER, supra note 42 , at 57-58; BERTRAND, supra note 10, at 93-98.

180. BERTRAND, supra note 10 , at 15.

181. This footnote is excerpted from a memorandum prepared by Agnès Dunogué, my research assistant. In France, the Commission Nationale de l'Informatique et des Libertés (CNIL) 
financial information is information "of a personal character," over which one must have control just as one must have control over one's image. ${ }^{182}$

The German approach is less directly interventionist. Credit reporting is provided not by government agencies, but by industry collectives known as "Schufas." Even in Germany, though, there is significant regulation: Consumers must sign a contractual clause expressly permitting lenders to share data about them, and before any data is shared, the law requires a careful balancing of the privacy interest of consumers against the interests of financial entities, theoretically in every individual case. As in France, moreover, German reporting focuses on classic sorts of negative information associated with insolvency and default. ${ }^{183}$ European credit reporting is thus the direct descendant of the old European law of bankruptcy: It is law that stigmatizes the dishonorable failure to pay one's debts, not law that allows merchants to pry into the buying habits of

is the administrative agency charged with protecting individuals' privacy, particularly in the context of computers and data processing, and ensuring that the relevant laws are enforced. See Commission Nationale de l'Informatique et des Libertés, at http://www.cnil.fr (last visited Nov. 11,2003 ). Financial institutions and specialized credit providers are subject to the CNIL's rules and supervision with regard to data processing. The creation and sharing of files containing what is referred to as "positive" and "nominative" data about consumers (i.e., personally identifiable information detailing account activity) is prohibited. Therefore, credit bureaus and credit reporting agencies (as they are known in the United States) do not currently exist in France. In order to collect and process personal data, approval from the CNIL must be obtained (in the form of what is referred to as a "récépissé"). See Délibération No. 87-025 of Feb. 10, 1987, JCP 1987, III, 59910 (reflecting the original version, which has since been amended three times).

What do exist in France, however, are accessible files containing "negative" credit information, that is, information about consumers who have defaulted on their payments. The Banque de France maintains a "Fichier National des Incidents de Remboursement des Crédits aux Particuliers" (FICP). Credit providers (such as banks or specialized companies) populate this database with information about individuals who have defaulted on credit payments (according to different rules depending on the type of credit account - for example, when a payment is not made for over ninety days after the due date for accounts that are not on a monthly payment plan). For more information, see BANQUE DE FRANCE, NOTE D'INFORMATION NO. 129: LE FICHER NATIONAL DES INCIDENTS DE REMBOURSEMENT DES CRÉDITS AUX PARTICULIERS (2002), at http://www.banque-france.fr/fr/telechar/2002/note 129.pdf. This database is accessible by all credit institutions established in France. If an individual is in the FICP, he or she will likely not be given credit again. The purpose of this database is to fight against "surendettement" (excessive debt).

182. See, e.g., SANDRA DE FAULTRIER-TRAVERS, ASPECTS JURIDIQUES DE L'INFORMATION 53-55 (1991) (explaining that financial information is information "à caractère personnel"); $i d$. at 51-53 (discussing the right to one's image).

183. See generally HANS-JÜRGEN SchaFFLAND \& NOEME WILTFANG, BUNDESDATENSCHUTZGESETZ (BDSG): ERGENZBÄRER KOMMENTAR NEBST EINSCHLÄGIGEN RECHTSVORSCHRIFTEN $\S 29$, paras. 17-18, at 6-7 (2000) (noting that a weighing of interests must be done for each individual case); id. para. 27, at 11 (noting reluctance to include "positive" data). The so-called "SCHUFA-Klauseln," the agreements to permit banks and other financial institutions to share information, are familiar to all Germans. See id. apps. 2-4 (reproducing the agreements). For the development of the German norms, see Dieter Ungnade \& Franz Josef Gorynia, Datenschutz und Kreditgewerbe, in ZEITSCHRIFT FÜR WIRTSCHAFTS- UND BANKRECHT (Sonderbeilage Nr. 7/1983, Wertpapier-Mitteilungen Teil IV). See also Ulrich Wuermeling, Scoring von Kreditrisken, 55 N.J.W. 3508 (2002). Credit scoring is provided only through statistical aggregation of anonymized data, in order to prevent violations of the privacy rights of individual consumers. 
honorable, solvent persons. Certainly anything like the American practice of compiling an accessible record of any individual's credit history seems like a dangerous exposure of private life to most Europeans.

All very continental - but at what cost? As any American law professor will surmise, it inevitably means that consumer credit is less easily available in continental Europe than it is in the United States. Indeed, these privacy norms must contribute significantly to the making of a continental world in which credit cards have made much slower progress than they have in the United States-a world that in general is not founded on the system of consumer credit. It may be difficult for Americans to understand why continental Europeans should resist our well-developed creditreporting practices. In the long run, good credit reporting ought to make life easier for everybody, and indeed make everybody richer. But, for the continental legal tradition, the basic issue is of course not just one of market efficiency. Consumers need more than credit. They need dignity. The idea that any random merchant might have access to the "image" of your financial history is simply too intuitively distasteful to people brought up in the continental world.

The protection of consumer data reflects in many ways the same clash of attitudes. Europeans have aggressively condemned traffic in consumer data: It is, European lawyers believe, a serious potential violation of the privacy rights of the consumer if marketers can purchase data about his or her preferences, and regulation is thus imperative. The resulting protections are embodied in the European Commission's forceful Privacy Directive of $1995,{ }^{184}$ under which Europeans claim the authority, as the Wall Street Journal puts it, to play "Privacy Cop to the World." ${ }^{185}$ Americans have of course been much slower and more hesitant to regulate, with the resulting battles that I have already described. ${ }^{186}$ And indeed, the continental attitude is not easy for Americans to understand. After all, there is a benefit in the traffic in consumer data. If marketers can learn more easily what my preferences are, they can provide me more easily with the goods and services I seek. To put it in the language of American law and economics, trafficking in consumer data lowers search costs: It makes it easier for buyers and sellers to find each other, creating sales that would otherwise not have been made, and thereby enhances the efficiency of the market. ${ }^{187}$

Not all Americans would approve of the theories of law and economics, of course. Nevertheless, on some level, the relaxed attitude of law-and-

184. For the text of the directive, see Data Privacy Directive, supra note 24 .

185. Scheer, supra note 25.

186. See supra notes $24-25$ and accompanying text.

187. For an amusing review of one new technology tracking consumer preferences in ways that some consumers reject, but others value (among them the author of this Article), see Jeffrey Zaslow, If Tivo Thinks You're Gay, Here's How To Set It Straight, Wall St. J., Nov. 26, 2002, at A1. 
economics scholars toward the market is clearly widely shared among American policymakers. This does not mean that Americans do not experience some anxiety about the traffic in their "private" information. But it does mean that American law has been far less categorical in its condemnations than European law. Whereas European law allows the collection of consumer data only for limited purposes and limited times, upon explicit consent of the affected person, and under government supervision, ${ }^{188}$ Americans are much more willing to tolerate industry selfregulation. ${ }^{189}$ Most of all, when they do propose regulation, they tend, in a characteristically American way, to favor "market-based solutions to personal data protection," as Pamela Samuelson writes, "over the strict comprehensive regulatory regime adopted . . . in Europe."

Indeed. Europeans have a harder time seeing the benefits of free-market solutions. As another leading scholar puts it, Europeans "trust government more than the private sector with personal information." ${ }^{\text {"191 }}$ Why is this? It is not hard to understand if we keep in mind the continental traditions I have described. Privacy is an aspect of personal dignity within the continental tradition, and personal dignity is never satisfactorily safeguarded by market mechanisms. Ever since the case of Dumas père, continental law has resisted the notion that one can definitively alienate one's "dignity." 192 Dignity, to this way of thinking, simply must be treated differently from property. As one French scholar insists, contrasting the American attitude with the French, one can freely dispose of one's liberty, but one can never be permitted to freely dispose of one's dignity. ${ }^{193}$ If one accepts that premise, one should accept the proposition that any consumer's consent to the sale of his or her data should have only limited effect at best. After all, "the importance of one's image," as a recent French article puts it, is greater than ever "in the information society."

Here again, consumers need more than cheap goods and services, just as they need more than easy credit. They need dignity. If your consumer profile is floating around somewhere in cyberspace, you are not in control

188. Data Privacy Directive, supra note 24, arts. 6(1)(b)-(c), (e), 7(a), 1995 O.J. (L 281) at 40 .

189. Scheer, supra note 25.

190. Pamela Samuelson, Privacy as Intellectual Property?, 52 STAN. L. REV. 1125, 1127-28 (2000). For Americans skeptical of such market solutions, see Julie E. Cohen, Examined Lives: Informational Privacy and the Subject as Object, 52 STAN. L. REV. 1373 (2000); and Paul M. Schwartz, Privacy and Democracy in Cyberspace, 52 VAND. L. REV. 1609 (1999).

191. Joel R. Reidenberg, E-Commerce and Trans-Atlantic Privacy, 38 HoUS. L. Rev. 717, $731(2001)$.

192. For limitations on such alienation in German law, see OSTERRIETH, supra note 80, at $168-69$

193. BEIGNIER, supra note 42 , at 61 . Bernard Beignier, I should note, would not accept my account here, since he places his emphasis much more on traditional postwar notions of human dignity.

194. De Lamberterie \& Strubel, supra note 44 , at 374. 
of your image. A just world, from this point of view, is a world in which everybody's respectability is carefully protected. ${ }^{195}$ This sort of thinking has far less resonance in America than it does in Germany and France. We will never quite share the intuitions that fuel the continental conviction that trading in consumer data must be prevented, or at least sharply limited by law.

As these examples suggest, continental privacy is not just for Princess Caroline, Princess Soraya, or Prince Ernst August. It is for the ordinary person as well, in his or her guise as consumer. It is also for the ordinary person in his or her guise as worker. Continental law has made considerable efforts to guarantee the privacy of workers in the workplace, at least within the limits of the possible. ${ }^{196}$ Worker e-mails, for example, are vigorously protected in a way that is not the case in America. ${ }^{197}$ There are protections for workers' other private documents, guarantees against video surveillance, and rights to use telephones for personal calls-all in the name of maintaining a certain "personal sphere." 198 It goes well beyond e-mails and the like, too, to cover a wide range of issues touching questions of workplace dignity. One striking French decision, for example, found it a violation of dignity rights when an employer in a retail store required that employees show a receipt for merchandise that they wished to take home. Treating workers with that sort of suspiciousness was regarded by the court as a violation of their expectation to be treated as honorable persons. ${ }^{199}$

The contrast with American approaches to the workplace is telling. American privacy protections, at their metaphoric core, are the sorts of protections afforded by the walls of one's home. They have been extended beyond the literal home, of course, since the eighteenth century. Nevertheless, it remains the case that American protections become progressively weaker the further the affected person is from home. This is particularly true when courts apply the "reasonable expectation of privacy" test developed in the Fourth Amendment context. ${ }^{200}$ The primary locus of one's "reasonable expectation of privacy" is of course in the home, and persons outside the home have correspondingly few privacy protections.

195. Thus, "information professionals" (i.e., journalists) are subject under French law to an obligation of "objectivity," which is part of the right to one's image. See LAURE MARINO, RESPONSABILITÉ CIVILE ACTIVITÉ D'INFORMATION ET MÉDIAS 145-94 (1997); de Lamberterie \& Strubel, supra note 44 , at $357-58$.

196. BERTRAND, supra note 10, at 111-22; Manfred Weiss \& Barbara Geck, Worker Privacy in Germany, 17 COMP. LAB. L.J. 75 (1995). For a detailed contrast between German and American approaches, see Matthew W. Finkin, Menschenbild: The Conception of the Employee as a Person in Western Law, 23 COMP. LAAB. L. \& POL'Y J. 577 (2002). See also Friedman \& Whitman, supra note 54, at 357-58.

197. See Bourrie-Quenillet \& Rodhain, supra note 29.

198. BERTRAND, supra note 10, at 117-22.

199. See Friedman \& Whitman, supra note 54, at 260.

200. See O'Connor v. Ortega, 480 U.S. 709 (1987) (applying a "reasonable expectation of privacy" test in determining whether a workplace search was constitutional). 
This applies to workers as well, whose expectation of privacy in the workplace, according to the American cases, is sometimes close to nil. ${ }^{201}$

The same contrast holds in one of the most striking aspects of the comparative law of privacy: the treatment of criminal offenders, including accused persons and prison inmates. Continental privacy protections extend to these classes of persons as well. Continental privacy law has been strongly concerned with the privacy rights of persons caught up in the toils of the justice system. In Germany, modern personality protection grows preeminently out of a 1976 case involving a homosexual prison inmate convicted of an act of terrorism. ${ }^{202}$ In that case, Lebach, the German Constitutional Court found that it would be a violation of the inmate's personality rights to broadcast a made-for-television movie about him. Lebach has been regarded since as the font of late-twentieth-century personality doctrine. French law too has made strong efforts to guarantee the privacy of accused persons as a fundamental aspect of the presumption of innocence, ${ }^{203}$ and more broadly of the "honorability" of the accused. ${ }^{204}$ In line with this, both Germany and France make considerable efforts to guarantee that prison inmates will enjoy protections for their privacy, in ways that are unimaginable for Americans. ${ }^{205}$ All persons haled into the criminal justice system enjoy, at least in principle, protections that are not available to their American counterparts.

201. E.g., Thompson v. Johnson County Cmty. Coll., 930 F. Supp. 501 (D. Kan. 1996), aff'd, 108 F.3d 1388 (10th Cir. 1997) (unpublished table decision).

202. BVerfGE 35, 202. On Lebach, see MEDIENWIRKUNG UND MEDIENVERANTWORTUNG (Friedrich Kübler ed., 1975). The Lebach doctrine has now been altered somewhat by the socalled Lebach II decision. BVerfG, 1 BvR 348/98, 1 BvR 755/98, v. 25.11.1999. These are not mechanically applied principles, of course. See, e.g., Walter Seitz, Einmal Nackt-Immer Frei?, 55 N.J.W. 3231 (2002) (noting that a dossier compiled during an investigation may be kept even after the acquittal of the defendant under some circumstances). For a survey of the current state of German law with regard to the accused at trial, see $\S 169$, paras. 14-20, 26 GERICHTSVERFASSUNGSGESETZ (Otto Kissel ed., 3d ed. 2001) (discussing the dangers of exposure for the accused); $i d$. $\S 169$, paras. $85-93$ (discussing press coverage); id. $\S \S 171 \mathrm{a}-171 \mathrm{~b}$ (discussing the closing of trials, in part in order to protect privacy). Germans feel the tension between the imperative of the public openness of the courts and the need for the protection of personality quite acutely. See Bodo Pieroth, Gerichtsöffentlichkeit und Persönlichkeitsschutz, in RECHT DER PERSÖNLICHKEIT, supra note 76, at 249. For the law of press reporting, which certainly does leave room for much detailed publication-as readers of German newspapers will know-see also KARL EGBERT WENZEL, DAS RECHT DER WORT- UND BILDBERICHTERSTATTUNG 448-49 (4th rev. ed. 1994).

203. C. CIV. art. 9-1 (amended 1992). For a fuller account, see PIERRE KAYSER, LA Protection de la VIe Privée PaR le Droit: Protection du Secret de la Vie Privée 17375 (3d ed. 1995).

204. Jean Dematteis \& Nadein Poulet-Gibot Leclerc, Peut-on Supprimer l'Article II du Code de Procédure Pénale relatif au secret de l'instruction?, JCP, Oct. 9, 2002, LEXIS, Nexis Library, La Semaine Juridique, édition générale File. This article describes the real tension between the ideal of the "honorability" of the accused and the ideal of freedom of the press. Cf. Paul v. Davis, 424 U.S. 693 (1976) (demonstrating the contrary approach of U.S. law by permitting the public posting of a photograph of an "active shoplifter" against whom charges had been dropped).

205. See WhitMan, supra note 55, at 84-92. For German debates on whether guards must always knock before entering a prisoner's cell, see $i d$. at 90 . 


\section{CONTEMPORARY CONTINENTAL LAW: FREE EXPRESSION AND PUBLIC NUDITY}

Differences in cultural tradition, in short, have made for palpable differences in law. The differences are most striking, and most categorical, where the values of free speech are involved. Here it is above all the classic problems of privacy law-sex and nudity-that provide the most revealing examples. They are my topic in this last Part discussing continental law.

With regard to France, some of the striking contrasts in the law were traced by Jeanne Hauch in a 1994 article with the wonderful title Protecting Private Facts in France: The Warren \& Brandeis Tort Is Alive and Well and Flourishing in Paris. ${ }^{206}$ Hauch offers, among others, the example of Oliver Sipple. ${ }^{207}$ Sipple was the unfortunate man who thwarted the attempt of Sara Jane Moore to assassinate President Gerald Ford. He was homosexual-a fact that he very much wanted kept out of the press. This proved to be impossible under the American law of "public figures." Of course, in any democracy the private doings of at least some public figures are a matter of legitimate public interest, and every democratic system recognizes that. ${ }^{208}$ Since the 1960 s, though, the American "newsworthiness" exception has grown mightily, and peculiarly, in scope ${ }^{209}$ Freedom of expression is a value of constitutional magnitude in the United States, whereas the protection of personal honor is not, which means that freedom of expression almost always wins out. That is what doomed Oliver Sipple's effort to keep his homosexuality out of the papers. Although Sipple's entry into the public eye was the result only of his heroism in a moment of danger, the California Court of Appeal held that there was a legitimate public interest in his private life. In any case, the court held, "he did not make a secret" of his sexual orientation, at least in San Francisco. ${ }^{210}$ Sipple (whose family in the Midwest had known nothing of his California life) eventually committed suicide. ${ }^{211}$

206. Jeanne M. Hauch, Protecting Private Facts in France: The Warren \& Brandeis Tort Is Alive and Well and Flourishing in Paris, 68 TUL. L. REV. 1219 (1994).

207. Id. at 1220,1263 n. 217 .

208. For a summary of such recognitions in Germany, see $\$ 23 \mathrm{KUG}$, amended by Gesetz, v. 22.2.2001 art. 3, $\S 31$ (BGBl. I S.280). See also, e.g., SOEHRING, supra note 79, at 427-28, 434-37.

209. See Harry Kalven, Jr., Privacy in Tort Law-Were Warren and Brandeis Wrong?, 31 LAW \& CONTEMP. PROBS. 326, 335-38 (1966) (noting what has been a spiraling growth in the newsworthiness exception ever since Warren and Brandeis's article was published).

210. Sipple v. Chronicle Publ'g Co., 201 Cal. Rptr. 665, 669 (Ct. App. 1984). An example frequently paired with this case is Haynes v. Alfred A. Knopf, Inc., 8 F.3d 1222 (7th Cir. 1993), in which the court held that the publication of arguably embarrassing facts about the plaintiff did not constitute libel.

211. ROSEN, supra note 46 , at 48. 
It is precisely cases like this that Europeans see differently. The right of free expression that protects the press is always balanced in continental Europe against an individual right to "dignity," "honor," or "personality,"212 which implies a right to personal privacy-as was shown by a 1985 French case that Hauch uses as a foil to the Sipple decision. ${ }^{213}$ The case involved a man who attended a gay pride parade in Paris, dressed in a way that made it clear that he was himself gay. His image was captured in a news photo. Continental law has long held that persons appearing in public may be photographed, but that no photograph may be published that focuses on them as individuals, unless they consent. Moreover, to the French way of thinking, the fact that one has revealed oneself to a restricted public-say, the gay community of Paris-does not imply that one has lost all protections before the larger public. These principles matter, and the French court accordingly acknowledged the plaintiff's right to oppose publication of his image. ${ }^{214}$

The contrast between the treatment of Sipple and the treatment of this French victim of publicity is typical of a much deeper contrast in attitude, which one commentator on the supposed "failure" of American privacy law describes this way:

$[P]$ rivacy is not the only cherished American value. We also cherish information, and candour, and freedom of speech. We expect to be free to discover and discuss the secrets of our neighbours, celebrities, and public officials. We expect government to conduct its business publicly, even if that infringes the privacy of those caught up in the matter. Most of all, we expect the media to uncover the truth and report it-not merely the truth about government and public affairs, but the truth about people.

The law protects these expectations too-and when they collide with expectations of privacy, privacy almost always loses. ${ }^{215}$

In Europe, by contrast, personal honor very often wins out. As one German author put it in 1959-a time when Germans began to reassert their own distinctive national traditions-there is simply an inevitable tension between the worldview of a Goethe, for whom the development of

212. For a survey of German approaches and problems, see AHRENS, supra note 161. For French approaches, with comparisons to German and American law, see LAURENT PECH, LA. LIBERTÉ D'EXPRESSION ET SA LIMITATION 147-230 (2003).

213. See Hauch, supra note 206, at 1254-55.

214. CA Paris, le ch., June 14, 1985, D. 1986 inf. rap. 50, note R. Lindon. For discussions of the case, see BEIGNIER, supra note 42, at 54-55; and BERTRAND, supra note 10, at 92-93, 141.

215. Anderson, supra note 32, at 140. For a vigorous statement of this position, see Eugene Volokh, Freedom of Speech and Information Privacy: The Troubling Implications of a Right To Stop People from Speaking About You, 52 STAN. L. REV. 1049 (2000). 
"personality" was "the greatest blessing of the children of the earth," and the worldview of a Jefferson, for whom press liberty was the indispensable foundation of a free society. ${ }^{216}$ Europeans are by no means completely deaf to the pleas of Jefferson, but the attitude of Goethe always haunts their thinking too. That does not mean that Europeans are doctrinaire. They have their own doctrine of "public figures." But that doctrine cuts far less deeply, as numerous cases indicate. And even when the courts allow "intrusions" into the lives of "public figures," commentators grumble. ${ }^{217}$

Many more examples can be offered-most especially involving nudity, and most especially involving the Internet. In German and French legal culture, we still find much the same attitude that we found in the 1877 decision regarding Ingres's nude sketch of Madame Moitessier: One ought to have control over one's nude image. This means, of course, that one can sell the rights to an image, just as one can in America ${ }^{218}$-at least provisionally. Nevertheless, there are limits. In one 1974 case, for example, a French actress was permitted to suppress movie scenes in which she had willingly appeared naked: One's nude image is simply not definitively alienable under continental norms. ${ }^{219}$ In other cases, models have been able to suppress the republication of their nude photos in magazines other than the ones they posed for-a matter in which "French law," a commentator observes approvingly, "is ... totally opposed to American law." 220 The same sort of attitude has also affected both continental cyberlaw and the continental law of public nudity. The Internet has produced two recent leading cases in particular, one in Germany and one in France, in both of which courts imposed liability on Internet service providers that housed nude images of celebrities. In the German decision, Steffi Graf, the former

216. Löffler, Persönlichkeitsschutz und Meinungsfreiheit, 12 N.J.W. 1 (1959).

217. In France, most recently, there is the matter of Barcia c. S.A. Groupe Express, No. 2000/14309, slip op., CA Paris, le ch., Sept. 20, 2001. In that case, the court allowed the publication of a photograph of the head of the French Trotskyite party, who had appeared at a funeral. For grumbling about this decision, see Bertrand Mathieu \& Michel Verpeaux, Jurisprudence Constitutionnelle, JCP, Nov. 13, 2002, LEXIS, Nexis Library, La Semaine Juridique, édition générale File. For a German example, see the decision in the matter of the reproduction of a nude photo of Katarina Witt, published in Playboy magazine. The German court allowed the reproduction since it was in small format and clearly intended for purposes of satire or political commentary. OLG Frankfurt am Main, v. 21.9.1999, 11 U 28/29, 53 N.J.W. 594 (2000). For grumbling surrounding that decision, see Walter Seitz, Einmal nackt-immer frei?, 53 N.J.W. $2167(2000)$.

218. See, e.g., BEIGNIER, supra note 42, at 55; Bouvard, supra note 44, at 375-76.

219. See Bouvard, supra note 44 , at 382 (discussing Laure c. VM Productions, T.G.I. Paris, Mar. 14, 1974, D. 1974, p. 766, note R. Lindon). This indeed applies in principle more generally to sales of one's image. See BERTRAND, supra note 10, at 176. For German law wrestling with the problem of the limits of the alienability of nude images, see MARTIN LÖFFLER \& REINHART RICKER, HANDBUCH DES PRESSERECHTS 290-91 (2d rev. ed. 1986); Schadensersatz für Nacktfoto im Fernsehen, 38 N.J.W. 1617 (1985); and Unwirksamkeit einer Einwilligung in die Anfertigung pornografischer Fotos, 40 N.J.W. 1434 (1987).

220. BERTRAND, supra note 10, at 165. See generally id. at 163-67 (contrasting French and American law). 
tennis star, successfully sued Microsoft for its refusal to guarantee that it would prevent dissemination of a "fake"-a picture of her head superimposed on the nude body of another woman. ${ }^{221}$ The leading French case involved the model Estelle Hallyday, who similarly sued a service provider-this time a free service provider-for housing her nude image. Hallyday's suit put the provider in question out of business. ${ }^{222}$ There have been a number of such French cases since. ${ }^{223}$ Indeed, there has been criminal liability: One young man who published nude photos of his exgirlfriend on the Internet (with commentary) received a suspended sentence of eight months' imprisonment and a fine of 25,000 francs-a serious sentence in France. ${ }^{224}$ These cases do not establish an unconditional right. In particular, here again, European law does understand how to make exceptions for public figures. ${ }^{225}$ There is no absolute control over the dissemination of one's nude image in continental law. Nevertheless, there is no doubt that the continental courts are on the watch.

The situation is different in America. Theoretically, the same rights exist in some form in American law. Nevertheless, both culture and practice differ. Congress has passed legislation that aims to forbid imposing liability on Internet service providers as such. ${ }^{226}$ Perhaps more strikingly, unlike the European courts, American courts see little point in issuing injunctions once images have been irrevocably diffused over the Internet. ${ }^{227}$ Such was the fate, for example, of Dr. Laura Schlessinger, a well-known conservative radio commentator, who posed for some cheesy nude photos for a man who was her boyfriend and mentor in the 1960s. In 1998, Dr. Schlessinger's (now ex-) boyfriend sold the photos to Internet Entertainment Group (IEG),

221. See Graf Wins Suit over Fake Nude Photos, Miami Herald, May 29, 2002, at http://www.miami.com/mld/miamiherald/3357808.htm.

222. See Jean-Claude Patin, La responsabilité des hébergeurs $n{ }^{\circ} 2$, CHRONIQUES JURIDIQUES JURITEL, at $\mathrm{http}: / / \mathrm{www}$.juritel.com/Liste_des_chroniques-56.html (last visited Dec. 16, 2003).

223. For another much-discussed example, consider the case of Lynda Lacoste, a French model who obtained a similar injunction when her nude image was circulated by an Internet porn outfit. S.A. Multimania Prod. c. Madame L., No. 859, CA Versailles, 12ème ch., June 8, 2000; see also S.A. SPPI c. Société Fox Média, No. R6: 01/04400, T.G.I. Paris, 3ème ch., May 29, 2002.

224. BERTRAND, supra note 10, at 127.

225. As an example, we may take a recent German case involving Katarina Witt, the iceskating star who posed for Playboy magazine. The Frankfurter Allgemeine Zeitung was permitted to reproduce her nude photo, as long as it did so in a small format and in a context that clearly was intended to make a political statement. See supra note 217.

226. Communications Decency Act of $1996 \S 509,47$ U.S.C. $\$ 230(c)(1)$ (2000) ("No provider or user of an interactive computer service shall be treated as the publisher or speaker of any information provided by another information content provider."); see also Zeran v. Am. Online, Inc., 129 F.3d 327 (4th Cir. 1997) (interpreting the Act and finding no distributor liability for Internet service providers); Blumenthal v. Drudge, 992 F. Supp. 44, 49 (D.D.C. 1998) (same).

227. In describing this difference, Europeans usually refer, somewhat misleadingly, to the notorious case of the honeymoon video of Pamela Anderson Lee. E.g., BERTRAND, supra note 10, at 163 . However, that case had some peculiarities that make it, in fact, a poor example, since Lee had previously entered into a settlement that included a waiver of any right to sue. See David Rosenzweig, Celebrities Lose Nude Photo Cases, L.A. TIMES, Nov. 3, 1998, at B1. 
an organization that specialized in putting exactly such nude photos of celebrities online. IEG promptly put the photos on display. Indeed, in a show of almost parodic contempt for norms of privacy, the IEG site was equipped with technology that allowed paying viewers to zoom in on any part of Dr. Schlessinger's anatomy. ${ }^{228}$

There is little doubt that any continental court would have enjoined an outfit like this from distributing the photos. Even in America, Dr. Schlessinger did succeed in obtaining an injunction for a time. ${ }^{229}$ After a few weeks, though, the court lifted the injunction on the ground that the photos were already widely available on the Internet. ${ }^{230}$ From a certain point of view, of course, the real result of Dr. Schlessinger's suit was no different from the real result in the cases of Steffi Graf or Estelle Hallyday: The curious can still find the relevant nude pictures of all of these unfortunate celebrities online. (Indeed, critics of the Hallyday decision loudly complained that her nude images remained available on at least twenty sites.) $)^{231}$ But European courts still feel obliged to forbid the circulation of those pictures, even when it is futile to do so, in order to express the importance of protecting "private life." Moreover, European courts feel obliged to penalize the persons responsible, be they Internet service providers or delinquent ex-boyfriends. ${ }^{232}$ American law is, our French commentator observes, "radically different." 233

This is not, let me emphasize, because Europeans are more squeamish about nudity than Americans. Quite the contrary. Germans in particular appear fully nude in places like public parks (in the summer) and public coed saunas (in the winter) with a sans-gêne that Americans can hardly fathom; and French women go topless, not only on the beach, but also on the banks of the Seine. There are certainly limits: For example, one German court recently held that jogging in the raw went a bit too far. ${ }^{234}$ Nevertheless, as I began by observing, it is most assuredly the Americans

228. See Patrizia DiLucchio, Dr. Laura, How Could You?, SALON.COM, Nov. 3, 1998, at http://archive.salon.com/21st/feature/1998/11/03feature.html.

229. See Rosenzweig, supra note 227.

230. Id. This follows an older line of authority in American courts. See Heath v. Playboy Enters., Inc., 732 F. Supp. 1145, $1148-49$ (S.D. Fla. 1990) (finding that republication of facts already published cannot form the basis for an invasion of privacy claim); Ritzmann v. Weekly World News, Inc., 614 F. Supp. 1336, 1340-41 (N.D. Tex. 1985) (finding the same for a "private facts" claim).

231. See Hébergement à Risque, LiBÉRATION, Feb. 16, 1999, http://www.chez.com/jezequel/ archives/fev99/altem.html.

232. The cultural differences may indeed run deeper than that: American celebrities-though "fakes" of many of them are to be had on the Internet too-apparently do not feel moved to sue in the way Steffi Graf did. American legal culture is just less oriented to the suppression of unauthorized nude images than is continental legal culture.

233. BERTRAND, supra note 10 , at 168 .

234. See Helmut Kerscher, Richter stoppen Freiburger Nackt-Jogger, SÜDDEUTSCHE ZEITUNG, May 11, 2000, at 7 . 
who are most troubled, and even put off, by nudity. ${ }^{235}$ The difference is not that Europeans refuse to be seen nude, but that they insist that they want to be the ones who should determine when and under what circumstances they will be seen nude. The difference is that the decision to appear nude, for Europeans, belongs to their control of their image.

Indeed, even when they appear nude in public, individual Europeans have sometimes tried to claim a right not to be shown naked by the media. Scenes of naked bodies, whether on the beach or in the parks, are of course irresistibly tempting to journalists. Photographs are inevitably published, and the persons portrayed sometimes sue. Such suits are indeed the ultimate test of the continental notion that people should have absolute control over the diffusion of their image. These suits have failed in France. ${ }^{236}$ But German courts are less categorical. Under the German law of the right to one's image, the control of pictures of the naked body belongs "exclusively to the individual." 237 This was the rule at stake in the case of a Munich man who filed suit after newspaper photos were published showing him naked in the Englischer Garten. The court took his claim seriously enough to hold that he had in principle suffered harm to his "personality" rights, though it ruled against his claim for damages. Even in ruling against his claim for damages, though, the court emphasized that his genitals were not exposed in the photo. ${ }^{238}$ Had his genitals been exposed, the case might have come out differently. ${ }^{239}$ The German court thus found it important to state the principle that nude persons have a right to control their public face, just as clothed people do. In this, the law only tracks German sensibilities more broadly, and in particular the German etiquette of public nudity. Indeed, any serious scholar's research into continental privacy norms should include a good stint on a German Liegewiese. As any German there will tell you, it is a matter of ordinary politeness that nude people have a right not to be stared at. Taking off all your clothes, even in a public park, does not constitute a surrender of your privacy.

Such is the sort of attitude that we must grasp if we want to understand continental law: We must understand that there could be such a thing as private public nudity. It is an attitude that American law simply does not comprehend, as we can see most strikingly from the Supreme Court's 1995

235. For a sensitive comparative discussion of the German and American law of public nudity, see Mathias Reimann, Prurient Interest and Human Dignity: Pornography Regulation in West Germany and the United States, 21 U. MICH. J.L. REFORM 201, 232-41 (1987). I have suggested elsewhere that American law tends to emphasize decency norms over civility norms. Whitman, supra note 42 , at $1380-81 \& \mathrm{n} .343$. The law of public nudity raises a number of issues that I cannot deal with in depth in this Article.

236. See BERTRAND, supra note 10, at 160-61.

237. § 23, para. 2 KUG (amended 2001); see also SOEHRING, supra note 79, at 445. 70.

238. Bildveröffentlichung eines nackten Sonnenbaders, 1986 ARCHIV FÜR PRESSERECHT 69,

239. See id. 
decision in Vernonia School District $47 J v$. Acton. ${ }^{240}$ This was a case that presented the question of whether high school athletes could be subjected to mandatory drug testing. In holding that they could, the Supreme Court offered, among others, an argument that took the following form: Athletes regularly shower together in the nude. Since they voluntarily expose themselves through this "communal undress," they have a "reduced expectation of privacy" with regard to whether their urine will be tested for the presence of drugs: Once a person appears nude in public-even before a highly restricted public - he has, in the eyes of the Court, at least partly surrendered his claim to privacy. ${ }^{241}$ To the continental ear, this is a bizarre non sequitur. The fact that students have willingly appeared naked in one circumstance says strictly nothing about whether they have broadly surrendered their right to control access to data about them, and certainly nothing about whether they have consented to a urine test. ${ }^{242}$ For Americans, by contrast, the right to privacy is, at its metaphoric core, a right to hide behind the walls of one's own home. Those who have abandoned the protection of the home, and a fortiori the protection of clothing, have at best a diminished claim to privacy.

\section{WARREN AND BRANDEIS REVISITED}

Indeed, continental ideas of privacy are just not much at home in American legal culture. To be sure, there is certainly American law on the books that sounds something like what we find on the books of Germany or France. American law has its famous four forms of the privacy tort, as analyzed by William Prosser in 1960: intrusion upon seclusion, ${ }^{243}$ appropriation of the name or likeness of another, ${ }^{244}$ public disclosure of private facts "not of legitimate concern to the public," 245 and disclosure of private facts in such a way as to portray victims in a "false light." 246 There is considerable legislation too, like the Video Privacy Protection Act of $1987,{ }^{247}$ passed in reaction to journalistic investigations of Robert Bork, and various other acts and bills, both state and federal. American legislatures do pass privacy protection statutes of various kinds ${ }^{248}$ - especially, as Jeffrey

240. 515 U.S. 646 (1995).

241. Id. at 657. But see Bd. of Educ. of Indep. Sch. Dist. No. 92 v. Earls, 536 U.S. 822, 846-47 (2002) (finding that "communal undress" was not essential to the Vernonia holding).

242. For applications of this rule, see SOEHRING, supra note 79, at 450-52.

243. RESTATEMENT (SECOND) OF TORTS § 652B (1977).

244. Id. $\S 652 \mathrm{C}$.

245. Id. $\S 652 \mathrm{D}$.

246. Id. $\S 652 \mathrm{E}$.

247. 18 U.S.C. $\S 2710(2000)$.

248. For a survey, see ROBERT ELLIS SMITH, COMPILATION OF STATE AND FEDERAL PRIVACY LAWS (2002). 
Rosen has observed, in the wake of "heartstring-tugging" scandals. ${ }^{249}$ While many of these statutes treat the government as the principal threat to privacy, not all of them do. Though less than a third of the states have general laws on the protection of privacy, there certainly are state protections. ${ }^{250}$ There are even state constitutional protections for privacy. ${ }^{251}$ There are decisions giving protection to one's image-notably cases involving the nude or sexually charged images of young women who did not intentionally pose in a provocative way, ${ }^{252}$ or who are the victims of sexual assaults, ${ }^{253}$ or who otherwise seem to be living "a life of rectitude." 254 There are cases involving nongovernmental invasions of the "privacy of [the] home," 255 and especially of the privacy of the bedroom: ${ }^{256}$ Where the walls of the home are breached Americans can be sensitive. There is a lot of American scholarship that vigorously defends the European point of view. ${ }^{257}$ And of course, there is the famous article of Warren and Brandeis.

Nevertheless, as our many and heated conflicts with Europe suggest, the American attitude remains different. It is not true that American law is absolutely different from European law. No generalization about any legal system is ever absolutely correct: Law is always something of a jumble, and there are always exceptions to any general description. The differences that we can see are always comparative differences, not absolute ones. Nevertheless, the American climate of values remains basically inhospitable to the European way of looking at things. We do find patches of more or less continental law in America, just as patches of snow sometimes survive in a hollow on an early spring day. But over time, most efforts to make American law look more continental tend to melt away.

249. ROSEN, supra note 46, at 170 . For an example, see the Califormia Privacy Protection Act, CAL. CIV. CODE $\S 1708.8$ (West Supp. 1999), which was passed in the wake of the death of Princess Diana.

250. SOLOVE \& ROTENBERG, supra note 24 , at 25.

251. E.g., AlA. CONST. art. I, § 22; CAL. CONST. art. I, § 1; FLA. CONST. art. I, § 23.

252. E.g., Wood v. Hustler Magazine, 736 F.2d 1084 (5th Cir. 1984); Lake v. Wal-Mart Stores, Inc., 582 N.W.2d 231 (Minn. 1998) (discussing the circulation of photos that gave the false impression that the plaintiff was a lesbian). Women are not the only ones for whom American law shows this kind of concern. For a recent example involving a man, see Solano v. Playgirl, 292 F.3d 1078 (9th Cir.), cert. denied, 537 U.S. 1029 (2002).

253. See SANFord H. Kadish \& STEPHEN J. SChulHofer, CRIMINAL LAW AND ITS PROCESSES 375-86 (7th ed. 2001) (surveying evidentiary shield laws); see also N.Y. CIV. RIGHTS LAW $\S 50$-b (McKinney 1992); 42 PA. CONS. STAT. $\S 5988$ (2002).

254. Melvin v. Reid, 297 P. 91,93 (Cal. Dist. Ct. App. 1931).

255. Rhodes v. Graham, 37 S.W.2d 46, 47 (Ky. 1931), quoted in RICHARD C. TURKINGTON \& ANITA L. ALLEN, PRIVACY LaW: CASES AND MATERIALS 538 (2d ed. 2002).

256. Hamberger v. Eastman, 206 A.2d 239 (N.H. 1964). This case is a chestnut in the American privacy literature. See, e.g., POST, supra note 68, at 52-53; TURKINGTON \& ALLEN, supra note 255 , at $539-40$.

257. See supra notes 64-69 and accompanying text. 
This is indeed how we should understand the fate of "that most influential law review article of all," ${ }^{258}$ Warren and Brandeis's The Right to Privacy. ${ }^{259}$ Warren and Brandeis undertook the seminal, and still most cited, effort to introduce a continental-style right of privacy into American law. In theory, their right is still part of the law almost everywhere in America. Nevertheless, it is generally conceded that, after a century of legal history, it amounts to little in American practice today. ${ }^{260}$ The story of the relative failure of Warren and Brandeis is precisely a study in how poorly continental ideas do in the American climate.

In fact, it is best to think of the Warren and Brandeis tort not as a great American innovation, but as an unsuccessful continental transplant. For, though commentators have failed to recognize it, what the two authors set out to do was precisely to introduce the continental protection of privacy into America. It is hardly news that Warren and Brandeis worked in a world of Boston respectability closely akin to the high society of late-nineteenthcentury Europe. Warren was a Boston Brahmin, a child of one of the socially dominant families of the city. Brandeis was the son of BohemianJewish immigrants who had fled to America after $1848 .{ }^{261}$ Their article was written in a fit of outrage over newspaper reports of a party given by the Warrens, ${ }^{262}$ and its main target was the gossip pages of the "yellow press," which Warren and Brandeis were convinced represented a new phenomenon. ${ }^{263}$ Like a number of authors of the period, ${ }^{264}$ they were upset

258. Kalven, supra note 209 , at 327.

259. Warren \& Brandeis, supra note 69.

260. Rodney A. Smolla, Privacy and the First Amendment Right To Gather News, 67 GEO. WASH. L. REV. 1097, 1101 (1999); Diane L. Zimmerman, Requiem for a Heavyweight: A Farewell to Warren and Brandeis's Privacy Tort, 68 CORNELL L. REV. 291, 333-34, 340 (1983).

261. Allon Gal, BRANDEIS OF BOSTON 1-5 (1980).

262. There has been some confusion about this, but the basic story remains the same. See James H. Barron, Warren and Brandeis, The Right to Privacy, 4 Harv. L. Rev. 193 (1890): Demystifying a Landmark Citation, 13 SUFFOLK U. L. REV. 875, $891-94$ (1979); Zimmerman, supra note 260 , at $295-96$.

263. This was not true: Society reporting had been standard newspaper fare since the seventeenth century. Indeed, newspaper reporting in some ways began as society reporting. See, e.g., 11 LAROUSSE'S GRAND DictionNaIRE UNIVERSEL DU XIXE SIĖClE 63 (Paris, Administration du Grand Dictionnaire Universel 1874) (describing the aims of the Mercure de France, a newspaper founded in 1672 that was concerned in part with details of marriages and the like). What was true was that newspapers in the age of Warren and Brandeis, unlike newspapers of the seventeenth or eighteenth centuries, had a mass audience, so that society reporting could now be read, not only by society readers, but by people in all walks of life.

264. The most frequently cited are THOMAS M. COOLEY, LAW OF TORTS 29 (Chicago, Callaghan 2d ed. 1888) (1878); E.L. Godkin, The Right to Privacy, THE NATION, Dec. 25, 1890, at 496; and E.L. Godkin, The Rights of the Citizen: IV-To His Own Reputation, SCRIBNER's MAG., July 1890, at 58 [hereinafter Godkin, To His Own Reputation]. When Joseph Kohler denounced the American "right of privacy" in 1903, though, he cited none of these works. Instead, he cited Elbridge Adams and Percy Edwards. KOHLER, supra note 42, at 7 n.l (citing Elbridge L. Adams, The Law of Privacy, 175 N. AM. REV. 361 (1902); and Percy L. Edwards, Right of Privacy and Equity Relief, 55 CENT. L.J. 123 (1902)). 
by these press intrusions. "The press," the coauthors complained, "is overstepping in every direction the obvious bounds of propriety and of decency.... To occupy the indolent, column upon column is filled with idle gossip, which can only be procured by intrusion upon the domestic circle." ${ }^{265}$ The only answer to the challenge, they argued, was to insist on a "right to privacy." This would protect individuals not only against the press, but also against intrusive photographers and the like. Nor would the new right be confined to high-status people like the Warrens:

The design of the law must be to protect those persons with whose affairs the community has no legitimate concern, from being dragged into an undesirable and undesired publicity and to protect all persons, whatsoever[] their position or station, from having matters which they may properly prefer to keep private, made public against their will. ${ }^{266}$

All of this was obviously much in the continental style, up to and including its desire to level up, to guarantee the right of all citizens "whatsoever" to be safe from "undesirable and undesired publicity." The high-status tenor of the Warren and Brandeis article is indeed something any reader can see immediately, and critics of Warren and Brandeis have said so. ${ }^{267}$ But if we look closely at the article we can see something else: We can see that Warren and Brandeis took continental law as their starting point.

In fact, it is not difficult to retrace the research steps that Warren and Brandeis took. Like the authors of any law review article, they looked for authority for their position. The first and most natural place to look for their right to privacy, the two authors strikingly observed, lay in the protection of "honor" through the law of insult. And in the law of insult, they rightly noted, there were already lively traditions to draw upon in both France and Germany by the end of the nineteenth century. As we have seen, ${ }^{268}$ by 1890, when Warren and Brandeis wrote, the right to privacy was a longstanding topic of study and discussion within the continental traditions of the law of insult. Indeed, continental discussions were reaching a fever point in the $1880 \mathrm{~s}$. Warren and Brandeis were perfectly familiar with this. They cited the French privacy legislation of 1868 at length, and admiringly. ${ }^{269}$ They also cited German scholarship on the law of insult-in

265. Warren \& Brandeis, supra note 69, at 196.

266. Id. at 214-15 (emphasis added); see also Elbridge L. Adams, The Right of Privacy, and Its Relation to the Law of Libel, 39 AM. L. REV. 37 (1905).

267. See Don R. PEMBER, PrivaCy and the PRESS: The LAw, the Mass MEdia, AND the FIRST AMENDMENT 33-42 (1972); SOLOVE \& ROTENBERG, supra note 24, at 18.

268. See supra Parts IV-V.

269. Warren \& Brandeis, supra note 69 , at 214 n.1, 216 n.1, 218 n.2. 
particular Carl Salkowski's standard Institutes and History of Roman Private Law, ${ }^{270}$ a very German text, which interpreted ancient Roman law through the lens of German philosophy:

Iniuria in the narrower sense is every intentional and illegal violation of honour, i.e., the whole personality of another. ... This may be committed by insulting oral or written words or signs (socalled verbal and symbolic injuries), by deeds (so-called real injuries), by slander, and speeches and acts which cast suspicion upon, or are prejudicial to, the social or pecuniary position of any one, or other acts interfering with the right of personality. ${ }^{271}$

From Salkowski, or from some other German source, Warren and Brandeis borrowed the term "personality," and they characterized their right to privacy, in orthodox German fashion, as one aspect of the protection of "personality" more broadly. Indeed, it is likely that Warren and Brandeis knew more about the continental tradition than they chose to cite. Brandeis, who had been brought up in a Germanophile Louisville household, had been sent to high school in Germany during the 1870 s, and he remained a passionate admirer of German culture. ${ }^{272}$ It seems wholly improbable that he did not know of the lively German literature on "personality" when he adopted the term for his article. (If he only cited Salkowski it may be because Salkowski's was the only German text that had been translated into English.) Moreover, at least some of the French cases on the right to one's image must have been known to educated Bostonians. The Dumas case in particular had been an international cause célèbre. ${ }^{273}$ In any case, French privacy protections had been publicized by E.L. Godkin, an author often identified as an influence on Warren and Brandeis. ${ }^{274}$ As Godkin had explained, "In France a man can legally prevent or punish the mere mention of his name in any disagreeable connection, if he be not in political, literary or artistic life"- law that Godkin insightfully credited to a French "sensitiveness to ridicule or insult which has probably never existed in any Anglo-Saxon country.",275

Nevertheless, though Warren and Brandeis certainly knew the continental traditions, and cited them, they did not claim that it was possible to introduce continental practices directly into American law. They understood the continental tradition too well for that. The continental

270. Id. at 198 n.1.

271. Carl Salkowski, Institutes and History of ROMAN PRIVATE LAW 668-69 (E.E. Whitfield ed. \& trans., London, Stevens and Haynes 1886).

272. See GAL, supra note 261 , at 4-5.

273. MANKOWITZ, supra note 105, at 177-78.

274. See, e.g., Dorothy J. Glancy, The Invention of the Right to Privacy, 21 ARIZ. L. REV. 1, 2-3 (1979).

275. Godkin, To His Own Reputation, supra note 264, at 67. 
approach, they observed, was not available within the common law tradition-for the simple and insurmountable reason that the law of insult, and the protection of "personal honor," did not exist in America. "[O]ur system, unlike the Roman law, does not afford a remedy... for mental suffering which results from...contumely and insult [involving] an intentional and unwarranted violation of the 'honor' of another." 276 No matter how vigorous and appealing the ideas of Royer-Collard, Jhering, Gareis, Beaussire, and the rest might be, they could not be fitted into the common law precedents, which simply said nothing about personal honor, or at least nothing useful.

Warren and Brandeis's article thus started from the admission that the United States was doomed to be a nation without continental-style "privacy" protections, at least in their full form. But it continued by insisting that this was no cause for despair: Even in the absence of a law of insult, there were other resources to which one could turn. Indeed, Warren and Brandeis maintained, the protection of "honor" was not as promising a vehicle for the protection of "privacy" as continental writers imagined. The apparent analogy between honor and privacy was merely "superficial." Another road would have to be taken:

It is not however necessary, in order to sustain the view that the common law recognizes and upholds a principle applicable to cases of invasion of privacy, to invoke the analogy, which is but superficial, to injuries sustained, either by an attack upon reputation or by what the civilians called a violation of honor; for the legal doctrines relating to infractions of what is ordinarily termed the common-law right to intellectual and artistic property are, it is believed, but instances and applications of a general right to privacy, which properly understood afford a remedy for the evils under consideration. ${ }^{277}$

There was no ultimate need for "honor" in order to protect privacy; artists' rights would do. But even here, of course, Warren and Brandeis were pursuing a continental tack, and most particularly a German one. The Germans, as we have seen, ${ }^{278}$ had created their law of personality by drawing both on the law of insult and on Urheberrecht, on intellectual and artistic property. This is exactly what Warren and Brandeis, like Gareis and Kohler before them, did as well.

The resulting article is, of course, a common law classic, a tour de force effort to capture the drift of a case law system in a state of productive flux. Yet let us note that, even in their account of common law evolution, Warren

276. Warren \& Brandeis, supra note 69 , at 198.

277. $I d$.

278. See supra notes $146-150$ and accompanying text. 
and Brandeis did not sound all that different from their continental, and especially German, predecessors. As we have seen, French and German writers held that privacy had emerged as a limitation on property, ${ }^{279}$ and an evolutionary outgrowth of the growing sensitivity to the needs of "personality." 280 Warren and Brandeis echoed these ideas. In a style unmistakably like that of Jhering, they tried to trace the evolving "spirit" of the law. Copyright, rights in "intellectual and artistic property," they observed, had always been understood as a property right. ${ }^{281}$ Yet primitive ideas of property were falling by the wayside as the common law evolved. It was a general evolutionary trend of the common law to get beyond the protection of mere material "property rights," offering new protections for the immaterial damage of emotional and moral harms. ${ }^{282}$ This was true of privacy as well. Cases that had been interpreted as property cases, as cases in copyright, in fact revealed a growing judicial sense that it was necessary to "protect the privacy of the individual" from invasion-not just from the literal invasion of one's property, but from metaphorical invasions "either by the too enterprising press, the photographer, or the possessor of any other modern device for rewording or reproducing scenes or sounds." ${ }^{283}$ At the same time the common law of torts had gradually come to cognize the harm in various forms of mental suffering. ${ }^{284}$ These two trends conduced to the same evolutionary end: Common law thinking was giving rise to the new "Warren and Brandeis tort," the tort of invasion of privacy.

All of this made for an inspired contribution to the international literature on the protection of privacy-one that Europeans themselves still cite. ${ }^{285}$ But what Warren and Brandeis could not do was bring the European structure of values to the United States. Indeed, it was not just the continental law of insult that Warren and Brandeis were unable to introduce into America. It was much more broadly the constellation of ideas about personal honor that undergirded it.

The history of the cold reception that American law has given Warren and Brandeis has been written many times, and I will not repeat it here. I want only to emphasize that the American resistance to Warren and Brandeis has always been a resistance founded on two values in particular: the value of the free press, and the value of the free market. These are of course the very values that continental advocates of continental-style, honor-oriented privacy rights have long regarded with the greatest suspicion.

279. See supra notes 106-113 and accompanying text.

280. See supra Part V.

281. Warren \& Brandeis, supra note 69, at 200-05.

282. Id. at 198-207.

283. Id. at 206.

284. Id. at 193-95.

285. E.g., Badinter, supra note 174, para. 3; Beignier, supra note 10, at 141. 
Freedom of expression has been the most deadly enemy of continentalstyle privacy in America. To cite once again our German scholar of 1959, the conflict has always been one between the values of Jefferson and the values of Goethe. ${ }^{286}$ Of all American liberty values, freedom of the press is the most poisonous for continental-style privacy rights. Starting with the famous Sidis case of $1940,{ }^{287}$ American law began, in an American way, to favor the interests of the press at the cost of almost any claim to privacy. Perhaps the most striking examples come from the Supreme Court, with its decisions in Cox Broadcasting Corp. v. Cohn ${ }^{288}$ and Florida Star v. B.J.F. ${ }^{289}$ These were cases in which the media published the names of rape victims - in the latter case despite the fact that dissemination of the victim's name was a crime under state law. In both cases the Supreme Court found that the First Amendment protected media outlets against suit. ${ }^{290}$ Freedom of expression just about always wins in America-both in privacy cases and in cases involving infliction of emotional distress, like Hustler Magazine, Inc. v. Falwell, which denied recovery to preacher Jerry Falwell after Hustler published a particularly gross parody. ${ }^{291}$ This is the kind of question on which continental law, with its focus on personal honor, comes out differently. ${ }^{292}$

That does not mean, of course, that American law never protects the control of one's image. But even where it does, it tends to do it in an American way. This is perhaps clearest in the doctrine of the "right of publicity." The "right of publicity" is a characteristic American doctrinal invention, which we owe to Melville Nimmer's work of the $1950 \mathrm{~s}^{293}$ In a sense, it is a doctrine of the protection of one's image. Nimmer argued that persons had an ownership right in their image, and that they could sue others who had misappropriated it. But it should be obvious that the notion of one's image as a piece of property, as a commercial commodity, is different in spirit from the continental protection of image. And indeed, while continental lawyers endorse this American innovation, they are

286. See supra text accompanying note 216 .

287. Sidis v. F-R Publ'g Corp., 113 F.2d 806 (2d Cir. 1940).

288. 420 U.S. 469 (1975).

289. 491 U.S. 524 (1989); see also Bartnicki v. Vopper, 532 U.S. 514 (2001) (dealing with an intercepted cell phone conversation).

290. See also Time, Inc. v. Hill, 385 U.S. 374 (1967) (protecting the press against a "false light" privacy suit).

291. 485 U.S. 46 (1988).

292. See EBERLE, supra note 42, at 207-08 (discussing The Strauss Political Satire Case, BVerfGE 75, 369 (F.R.G.)).

293. Melville B. Nimmer, The Right of Publicity, 19 LAw \& CONTEMP. PROBS. 203 (1954) (drawing on the opinion of Judge Jerome Frank in Haelan Laboratories, Inc. v. Topps Chewing Gum, Inc., 202 F.2d 866 (2d Cir. 1953)). 
careful to distinguish it from their own distinctive traditions. ${ }^{294}$ (Indeed, Americans themselves are confused by the question of whether the right of publicity really belongs within the realm of privacy protections or not. $)^{295}$ And unsurprisingly, the American doctrine produces different results from continental doctrine. As critics complain, the "right of publicity" has tended to lose all of its moorings in the Warren and Brandeis idea of privacy, becoming essentially a vehicle for protecting the enterprises of celebrities like Bette Midler and Vanna White. ${ }^{296}$ Moreover, nothing in the doctrine of the "right of publicity" prevents Americans from alienating the rights in their image, no matter how humiliating their subsequent use may be. If your image is your property, you can sell it. In Europe, by contrast, as we have seen, sales of your nude image remain voidable 297 -a very important doctrine, in particular, for protecting the interests of persons who, in moments of youthful folly, have allowed themselves to be photographed in embarrassing positions.

Finally, an American interest in one's "publicity" is an interest in one's property, not an interest in one's honor. This too sets the American tradition apart from the continental, and it affects the analysis in such famous matters as the "Here's Johnny!" case. In that case, the entertainer Johnny Carson sued a portable toilet maker who had adopted the well-known tagline "Here's Johnny!" for its product. An appellate court held that Carson's publicity rights had been violated. But it was careful to insist that Carson's rights were commercial rights only, not privacy rights against humiliation or embarrassment. ${ }^{298}$ Here again, we can see a contrast with continental law, and with German law in particular. Even commercial enterprises can be "insulted" in Germany. German firms have "personality" rights, and they are indeed protected against embarrassing or humiliating uses of their slogans or logos, through what is called the doctrine of Markenverunglimpfung. ${ }^{299}$ Some cases litigated under the American "right

294. See, e.g., BERTRAND, supra note 10, at 137-38. For French struggles over this, see also Elisabeth Logeais \& Jean-Baptiste Schroeder, The French Right of Image: An Ambiguous Concept Protecting the Human Persona, 18 LOY. L.A. ENT. L. REV. 511 (1998).

295. For discussion with further references, see SOLOVE \& ROTENBERG, supra note 24, at 162-63.

296. See White v. Samsung Elecs. Am., Inc., 989 F.2d 1512 (9th Cir. 1993); Midler v. Ford Motor Co., 849 F.2d 460 (9th Cir. 1988). For a more developed recitation of this complaint, see Jonathan Kahn, Bringing Dignity Back to Light: Publicity Rights and the Eclipse of the Tort of Appropriation of Identity, 17 CARDOZO ARTS \& ENT. L.J. 213 (1999).

297. See BERTRAND, supra note 10, at 163 (discussing Pamela Anderson Lee, along with directions to a relevant Internet site); see also supra notes 219-233 and accompanying text.

298. Carson v. Here's Johnny Portable Toilets, Inc., 698 F.2d 831, 834-35 (6th Cir. 1983); see also Finger v. Omni Publ'ns Int'l, Ltd., 566 N.E.2d 141 (N.Y. 1990).

299. See the case known as Markenverunglimpfung $I, \quad \mathrm{BGHZ} 125,91$ (98), http://www.adicor.de/urteile.nsf/0/f71f1 18710a2d257c125687a002f3f0e?OpenDocument. French law is more relaxed on this issue. See de Lamberterie \& Strubel, supra note 44, at 343-44. There is of course also an American law of product disparagement, but its focus is characteristically more on proof of damages. See 50 AM. JUR. 2D Libel and Slander $\$ 551$ (2002). 
of publicity" may come out the same way that they would in European "right to one's image" cases. But the underlying values are different, and courts feel obliged to say as much.

Indeed, even if some cases come out the same way, many come out differently. And there are many areas of the law, as we have seen, where Americans do not even perceive the sorts of privacy violations that seem to Europeans obviously present. The Europeans are right. At the end of the day, Americans do not really grasp the European idea of the protection of privacy.

\section{The AMERICAN TRAdition: ProteCting THE SANCTITY OF THE HOME}

But does this mean that Americans don't understand the moral imperative of privacy in the creation of "personhood"? Such is the conclusion that commentators repeatedly draw, both in Europe and in the United States. Yet I hope it is clear that the problem is more complex than that. If Europeans protect "privacy," it is not because they understand universal moral truths that Americans fail to understand. It is because they live in societies that have been shaped by certain kinds of cultural expectations and certain kinds of egalitarian ideals. After many generations of experience, Europeans have come to value a certain kind of personhood: a kind of personhood founded in the commitment to a society in which every person, of every social station, has the right to put on a respectable public face; a society in which privacy rights are not just for royalty, but for everybody. This is a concept of personhood that has been formed by the peculiarities of continental culture and continental history, and it has produced a law of privacy that has been formed by the same culture and history. For persons who live in these continental cultures, there will always be some practices that seem, in an intuitively obvious way, to represent violations of privacy. Yet the same practices may not seem like violations at all to non-Europeans.

As for Americans: They have their own concepts of personhood, their own traditions, and their own values. And the consequence is that there will always be practices that intuitively seem to represent obvious violations to Americans. Most especially, state action will raise American hackles much more often than European ones.

This is indeed almost too obvious to need describing for American readers. Suspicion of the state has always stood at the foundation of American privacy thinking, and American scholarly writing and court doctrine continue to take it for granted that the state is the prime enemy of our privacy. To Americans, the starting point for the understanding of the right to privacy is of course to be sought in the late eighteenth century, and 
especially in the Bill of Rights, with its vigorous circumscription of state power. In particular, "privacy" begins with the Fourth Amendment: At its origin, the right to privacy is the right against unlawful searches and seizures. It is thus a right that inheres in us as free and sovereign political actors, masters in our own houses, which the state is ordinarily forbidden to invade. Over time, to the American mind, the early republican commitment to "privacy" has matured into a much more far-reaching right against state intrusion into our lives.

The classic statement of this American view came in 1886, at the same time that European scholars were developing their own characteristic ideas of privacy protections. The case was Boyd v. United States. ${ }^{300}$ In forbidding the government to seize the documents of a merchant in a customs case, the Supreme Court, after discussing the eighteenth-century background at length, issued an aggressive declaration of the "sanctity" of an American home. The court focused on a cause célèbre of the eighteenth century: the case of John Wilkes, the British political dissenter whose papers had been seized by government agents. ${ }^{301}$ In 1762 , Lord Camden had condemned such seizures in terms that helped inspire the American Bill of Rights. The Court rehearsed Camden's opinion — "a monument," as the Court put $\mathrm{it}^{302}$ and then continued:

The principles laid down in this opinion affect the very essence of constitutional liberty and security. They reach farther than the concrete form of the case then before the court, with its adventitious circumstances; they apply to all invasions on the part of the government and its employés of the sanctity of a man's home and the privacies of life. It is not the breaking of his doors, and the rummaging of his drawers, that constitutes the essence of the offence; but it is the invasion of his indefeasible right of personal security, personal liberty and private property, where that right has never been forfeited by his conviction of some public offence.... Breaking into a house and opening boxes and drawers are circumstances of aggravation; but any forcible and compulsory extortion of a man's own testimony or of his private papers to be used as evidence to convict him of crime or to forfeit his goods, is within the condemnation of that judgment. ${ }^{303}$

In later generations, the Supreme Court retreated from its uncompromising stance on the particular issue in Boyd, the government's 
access to papers. ${ }^{304}$ Nevertheless, Boyd's fundamental understanding of "privacy" rights as generalizations of the principle of the "sanctity of the home" has survived. Indeed, the standard history of modern American privacy rights should really begin, not with Warren and Brandeis's distant and dim echo of continental ideas, but with Boyd v. United States, four years earlier.

To be sure, American scholars and judges have repeatedly tried to graft a continental-style dignity standard on to this Fourth Amendment tradition. In the twentieth century, the most familiar attempt of this kind came from Louis Brandeis himself, by then a Supreme Court Justice, writing to dissent from a 1928 holding that wiretapping was not an invasion of privacy. Brandeis's famous dissent in that case, Olmstead v. United States, recast his 1890 "right to privacy" in a typically American way, as a Fourth Amendment matter. ${ }^{305}$ This dissent is cited often and enthusiastically by privacy advocates, but what is most remarkable about it is the way in which it lumped two distinct concepts of privacy together-only one of which had a clear basis in constitutional authority:

The makers of our Constitution undertook to secure conditions favorable to the pursuit of happiness. They recognized the significance of man's spiritual nature, of his feelings and of his intellect. They knew that only a part of the pain, pleasure and satisfactions of life are to be found in material things. They sought to protect Americans in their beliefs, their thoughts, their emotions and their sensations. They conferred, as against the Government, the right to be let alone- the most comprehensive of rights and the right most valued by civilized men. To protect that right, every unjustifiable intrusion by the Government upon the privacy of the individual, whatever the means employed, must be deemed a violation of the Fourth Amendment. ${ }^{306}$

The "pursuit of happiness," if it need be said, is of course not a phrase from the Constitution. ${ }^{307}$ What Brandeis was able to identify was a core constitutional right against the state, which he tried-nobly, if you will-to extend well beyond its original circumstances. Later Fourth Amendment jurisprudence took the same tack-for example in Schmerber v. California, which described the Fourth Amendment as protecting "privacy and dignity against unwarranted intrusion by the State." ${ }^{.08}$ Here again, though, the

304. See Fisher v. United States, 425 U.S. 391 (1976); Couch v. United States, 409 U.S. 322 (1973); Warden v. Hayden, 387 U.S. 294 (1967).

305. 277 U.S. 438, 471-85 (1928) (Brandeis, J., dissenting), overruled by Katz v. United States, 389 U.S. 347 (1967), and Berger v. New York, 388 U.S. 41 (1967).

306. Id. at 478 (emphasis added).

307. THE DECLARATION OF INDEPENDENCE para. 2 (U.S. 1776).

308. 384 U.S. 757, 767 (1966) (emphasis added). 
reasoning was most emphatically about the state, with no discernible doctrinal content given to the "dignity" interest.

That tradition has now continued with Lawrence $v$. Texas, the Supreme Court's striking 2002 Term opinion on homosexuality: "Liberty," the Lawrence opinion begins, "protects the person from unwarranted government intrusions into a dwelling or other private places." ${ }^{309}$ This is familiar, indeed well-worn, American language, but it is not the only language that the decision speaks. It also speaks the language of dignity: Lawrence insists movingly on the right of gays not to be "demeaned," on their right to enjoy respect. ${ }^{310}$ But once again, as has so long been the case, the Lawrence Court finds no doctrinal hook on which to hang its talk of "respect." There is language about respect in Lawrence, but there is little that can be said to count in any certain way as law. One wonders indeed whether "respect," as discussed by the Court in Lawrence, really has much future in American law. One hopes that it does. There is some authority that insists on privacy protections for sexual orientation as an "intimate aspect of . . personality.",311 In other circumstances, too, dignity sometimes seems to play an authentically important role in the application of Fourth Amendment norms. ${ }^{312}$ History suggests, though, that such arguments will fade in American discourse with time. This makes the prospects for a constitutionalized right to gay marriage, for example, dim.

What matters in America, over the long run, is liberty against the state within the privacy of one's home. This does not mean that the American approach to "privacy" is narrowly limited to Fourth Amendment search and seizure problems, of course. Lawyers do ingenious things, and the conception of privacy as liberty within the sanctity of the home can be extended in important ways. This has been notably true, of course, in the famous series of "constitutional privacy" decisions that began with Griswold v. Connecticut. ${ }^{313}$ At the limit, for those who accept the reasoning in Roe v. Wade, the modern right to "privacy" is the right to keep the government from intervening in our "private" decision about whether or not to abort an unwanted fetus; just as for others it is the right to keep the government from taking away our firearms. When private actors breach the walls of our homes, they too may sometimes raise our legal hackles-like the much-cited New Hampshire landlord of Hamberger v. Eastman, who bugged his tenants' bedroom. ${ }^{314}$

309. 123 S. Ct. 2472, 2475 (2003).

310. Id. at 2482 .

311. Sterling v. Borough of Minersville, 232 F.3d 190, 196 (3d Cir. 2000).

312. E.g., Lauro v. Charles, 219 F.3d 202 (2d Cir. 2000) (holding that "perp walks" violate a dignity interest when not sufficiently related to a legitimate government objective).

313. 381 U.S. 479 (1965).

314. 206 A.2d 239 (N.H. 1964). 
Nevertheless, the fundamental limit on American thinking always remains: American "privacy" law, however ingenious its elaborations, always tends to imagine the home as the primary defense, and the state as the primary enemy. This gives American privacy law a distinctive coloration. Where American law perceives a threat to privacy, it is typically precisely because the state has become involved in the transaction. The case of Hanlon v. Berger-also commonly known as "the CNN case"-makes a fine example. ${ }^{315}$ As we saw before, the Supreme Court found no violation of privacy rights when, in the Florida Star case, a newspaper published the name of a rape victim. The result was different in Hanlon: There the Court found a violation of privacy where a TV news crew went on a "ride-along" during a police raid. Once the police come into it, American intuitions shift. Another important example is Whalen v. Roe, the leading American informational privacy case. ${ }^{316}$ Predictably, that was a case involving government collection of private information. In general, the really easy cases in the American tradition are the ones involving, or resembling, criminal investigations. ${ }^{317}$ You can count on Americans to see privacy violations once the state gets into the act-in particular, where the issue can be somehow analogized to penetration into the home, or sometimes the body. ${ }^{318}$ Otherwise, you can never be sure. But you can count on Americans

315. 526 U.S. 808 (1999); see also Wilson v. Layne, 526 U.S. 603 (1999) (Hanlon's companion case); Oziel v. Superior Court, 273 Cal. Rptr. 196, 207 (Ct. App. 1990); RoSEN, supra note 46 , at $42-43$ (discussing these cases).

316. 429 U.S. 589 (1977). It is not clear how far the "right" established even in this case reaches. See Am. Fed'n of Gov't Employees v. Dep't of Hous. \& Urban Dev., 118 F.3d 786 (D.C. Cir. 1997).

317. See Ferguson v. City of Charleston, 532 U.S. 67 (2001) (holding that drug testing is an invasion of privacy where state law enforcement is involved).

318. This is true despite the famous pronouncement in Katz $v$. United States that the Fourth Amendment "protects people, not places." 389 U.S. 347, 351 (1967). For the requirement of a "physical invasion," see Silverman v. United States, 365 U.S. 505 (1961). For the special place of the home, see Payton v. New York, 445 U.S. 573 (1980). For a famous obscenity case hinging on the penetration of the home, see FCC v. Pacifica Foundation, 438 U.S. 726 (1978). But see Shulman v. Group W Prods., Inc., 955 P.2d 469, 490 (Cal. 1998) (finding no violation where an accident victim was filmed and recorded at the scene, but a possible violation where a metaphorical or literal "zone of physical or sensory privacy" was invaded). As the Restatement puts it,

The defendant is subject to liability under the rule stated in this Section only when he has intruded into a private place, or has otherwise invaded a private seclusion that the plaintiff has thrown about his person or affairs. Thus there is no liability for the examination of a public record concerning the plaintiff, or of documents that the plaintiff is required to keep and make available for public inspection. Nor is there liability for observing him or even taking his photograph while he is walking on the public highway, since he is not then in seclusion, and his appearance is public and open to the public eye. Even in a public place, however, there may be some matters about the plaintiff, such as his underwear or lack of it, that are not exhibited to the public gaze; and there may still be invasion of privacy when there is intrusion upon these matters.

RESTATEMENT (SECOND) OF TORTS $§ 652 \mathrm{~B} \mathrm{cmt.} \mathrm{c} \mathrm{(1977).} \mathrm{Or} \mathrm{again,} \mathrm{consider} \mathrm{Erwin} \mathrm{Chemerinsky}$ defending the constitutionality of the California Privacy Protection Act, CAL. Civ. CoDE $\$ 1708.8$ (West Supp. 1999). Chemerinsky takes his basic analysis from the Fourth Amendment: "Simply 
to see violations once the state is involved, and that means that there will always be continental practices that seem acceptable to Europeans but objectionable to us.

This is certainly not, once again, because continental eyes perceive no dangers emanating from the state. There are continental protections against searches and the like, though in practice they are somewhat less extensive than American protections. ${ }^{319}$ There are also continental decisions like the well-known German census cases, which limited access to German census data. ${ }^{320}$ Continental observers certainly understand how to distrust the state in some cases, just as Americans certainly understand how to protect people, in some cases, from embarrassing appropriations of their image. The differences are relative, and not absolute, as always.

Nevertheless, they are real differences, and they do mean that there are always some continental practices that seem just as obviously untroubling to German or French people as they seem obviously wrong to Americans. I offered numerous examples at the beginning of this Article. For the sake of brevity, let me focus on just one before concluding: the law of names. Continental governments reserve to themselves the right to refuse to register certain given names that parents have chosen for their infants. This is done differently in different countries. In Germany, the local registry office, the Standesamt, maintains a list of permissible names. ${ }^{321}$ After reforms in 1993, the state has more limited powers in France. Today, local French officials can issue a complaint if parents choose a name that those officials deem to be not in the best interests of the newborn child. A court will then be seized of the matter, and will decide if the name is an acceptable one. If it rejects the parents' choice, the court itself is to choose a name for the infant in question, if necessary. ${ }^{322}$

put, the law is constitutional because it substantially advances the government's interest in safeguarding privacy in the home." Erwin Chemerinsky, Protect the Press: A First Amendment Standard for Safeguarding Aggressive Newsgathering, 33 U. RICH. L. REV. 1143, 1164 (2000). Not every court is willing to extend such "invasion of property" reasoning, though. See, e.g., Desnick v. Am. Broad. Cos., 44 F.3d 1345 (7th Cir. 1995) (declining to extend trespass or Fourth Amendment reasoning in the case of a journalistic exposé).

For cases dealing with penetration into the body, see Union Pacific Railway Co. v. Botsford, 141 U.S. 250 (1891); and COOLEY, supra note 264, at 29.

319. See DAMASKA, supra note 39 , at 13-14, 23-24.

320. See The Census Act Case, BVerfGE 65, 1; The Microcensus Case, BVerfGE 27, 1.

321. The regulations are found in section 262 of the Allgemeine Verwaltungsvorschrift zum Personenstandsgesetz (Dienstanweisung für die Standesbeamten und ihre Aufsichtsbehörden), v. 31.1.1995 (on file with author). Germans, in my experience, are well aware of this. For a popular guide to the current state of affairs, consult Namensgebung - Geburtsanzeige beim Standesamt, http://www.geburtskanal.de/Wissen/N/Namensgebung_GeburtsanzeigeStandesamt.shtml (last visited Oct. 3, 2003).

322. C. CIV. art. 57. For a survey of the history of the French law of names, see NICOLE LAPIERRE, ChANGER DE NOM (1995); and ANNE LEFEBVRE-TEILlARD, LE NOM: DROIT ET HISTOIRE (1990). 
These are practices that seem strange indeed to Americans-how can a judge name your baby? - but they are widely defended by Europeans. Most commonly, Europeans say that the state simply must intervene to protect children against the stupidities of their parents. Indeed, to judge from my own conversations, the popular mind is vividly conscious of the problem of parental stupidity. It is a problem that is exemplified in particular, for ordinary Europeans, by the case of a French child named by her parents "Mégane Renaud." "Mégane" is the French version of the American name "Megan," one of a number of American names that became popular in France in the 1980s and 1990s. "Mégane" is however also the name of a popular car model marketed by the French manufacturer Renault (pronounced in the same way as "Renaud"). Thus two bits of French popular culture came together in an unfortunate way when parents with the surname "Renaud" chose to call their newborn daughter "Mégane." Local officials made a highly publicized (though ultimately unsuccessful) intervention, apparently believing that it was too much to saddle a child with a name something like the equivalent of "Camry Toyota." 324 There are other recent cases, too, in which parents have been prevented from giving their children names that are "ridiculous, pejorative, or in bad taste." 325 One Belgian woman, for example, was recently forbidden to name her newborn "Anakin," after the character in the Star Wars movie series. Despite her threat to go on a hunger strike, officials decreed that her child was to be called "Dorian." 326 There is even European human rights law on the issue. The case in question involved a French couple that chose to name their child "Fleur de Marie" ("Mary's Flower"), a name rejected by local officials on the ground that it was not a proper saint's name. That decision was litigated all the way to the European Court of Human Rights, which held, in 1996, with a Canadian judge dissenting, that the law of names did not represent a cognizable violation of the right of privacy. ${ }^{327}$

323. For two leading examples, see Résultats statistiques: Le graphique ci-dessous indique le nombre annuel de bébés français qui ont reçu le prénom JENNIFER, at http://www.meilleursprenoms.com/stats/histogram.php3?recherche=jennifer (last visited Dec. 4, 2003); and Résultats statistiques: Le graphique ci-dessous indique le nombre annuel de bébés français qui ont reçu le prénom KEVIN, at http://www.meilleursprenoms.com/stats/ histogram.php3?recherche=kevin (last visited Dec. 4, 2003).

324. CA Rennes, 6e ch., May 4, 2000, J.C.P. 2001, IV, 2655, note Pierre \& Boizard. The court's opinion emphasized that the parents had not had any "arrières-pensées"-that is, any unacknowledged or ulterior intentions, and that the car model in question would likely go out of production by the time the child reached school age.

325. For discussion and citations, see MÉGA CODE CIVIL 177 (Xavier Henry et al. eds., 5th ed. 2003) (commentary on Article 57, paragraph 3).

326. Nach dem "Krieg der Sterne" Kampf um einen Vornamen, FRANKFURTER AllgEMEINE ZEITUNG, Jan. 18, 2000, at 2.

327. Guillot v. France, App. No. $22500 / 93$ (Eur. Ct. H.R. Oct. 24, 1996), http://www.worldlii.org/int/cases/IIHRL/1996/80.html. A Belgian judge also dissented. There is of course no uniform orthodoxy on these questions in any country. 
All very strange to Americans. To be sure, the law of names has been loosening up, both in France and Germany. French law has eased up noticeably since the early $1990 \mathrm{~s}^{328}$ In the last few years, cases have been few in France-though the standard commentary to the Civil Code speculates that this may be because prelitigation interventions by officials are sufficient to discourage unacceptable names. ${ }^{329}$ As for Germany: There, the most important challenges to the law of names came from the many resident non-Germans wishing to give their children ethnic names. The German government responded essentially by extending its list to include acceptable names for all recognized ethnic groups. These days, Germans can theoretically pick any name that comes from some culture, as long as it appears in the official "International Handbook of Given Names," is "according to its essence a given name" (family names cannot be used as first names), and conforms to the sex of the child. ${ }^{330}$ This is certainly looser than the regulation of the past-though in my experience, few Germans realize how much latitude they have. At any rate, the European law of names is certainly not normally applied in a doctrinaire or draconian way. It is a complex body of law, in a state of some flux, which deserves a longer treatment than I can give it here.

Nevertheless, however complex it may be, its very existence is simply weird to Americans. Indeed, if you tried to introduce a law of names into a state like Texas, you might face an armed rebellion. ${ }^{331}$ But does that mean that it is wrong or evil, by some universal standard, to have such a law of names? Europeans can see benefits in it-just as Americans can see benefits in extensive credit reporting. But the issue, here as in credit reporting, is not whether there are or are not identifiable benefits. The issue is whether a given privacy violation seems to fly in the face of fundamentally important social values. For Americans, the answer is very

328. This is especially true since the passage of Law No. 93-22 of Jan. 8, 1993, J.O., Jan. 9, 1993, p. 495 (amending C. CIV. art. 57), http://www.legifrance.gouv.fr/WAspad/ Visu?cid $=79562$ \&indice $=2 \&$ table $=$ JORF \&ligneDeb $=1$.

329. MÉGA CODE CIVIL, supra note 325, at 177 (commentary on Article 57, paragraph 3 ).

330. Officials are instructed to discourage applicants who seek to use irregular spellings. See Allgemeine Verwaltungsvorschrift zum Personenstandsgesetz, supra note 321. The current standard list can be found in the Internationales Handbuch der Vornamen, a description of which can be found at Internationales Handbuch der Vornamen, at http://www.vfst.de/xml/ fachliteratur_produkt.html?produktid=202 (last visited Oct. 28, 2003). For the case of a woman who went too far, choosing twelve names for her child as a multicultural statement, see Zwölf Namen sprengen den Personalausweis, SÜDDEUTSCHE ZEITUNG, June 21-22, 2000, at 16. For an interesting Nazi-era baby-naming pamphlet, see L. LECHNER, DIE NAMENSGEBUNG (1938). It includes not only a list of good German names, but also carefully scripted naming ceremonies, featuring swastika banners, pictures of the Führer, hymns to be recited by small children, and so on.

331. To be sure, the law of names is not entirely absent from American life. See In re Dengler, 246 N.W.2d 758 (N.D. 1976) (declining to permit "1069" as a personal name). The differences here as elsewhere are relative and not absolute. Nevertheless, I trust my American readers will agree that the differences are real, and dramatic. 
likely to be that the continental law of names does exactly that-flies in the face of important values of liberty. They may note that African Americans in particular, a historically oppressed population, express their independence partly through inventing unusual names for their children. ${ }^{332}$ But in any case, here as elsewhere, Americans will see an unacceptable violation of privacy where the state introduces itself into any "private" decision. Indeed, if drawn to defend themselves philosophically, Americans may use exactly the same imposing language of "personhood" that Europeans use in defending their conceptions of privacy. Is not the name fundamental to the making of the person?

\section{CONCLUSION}

I will not try to answer that last question, because the correct concept of personhood is not what is at stake here. What is at stake are two different core sets of values: On the one hand, a European interest in personal dignity, threatened primarily by the mass media; on the other hand, an American interest in liberty, threatened primarily by the government. On both sides of the Atlantic, these values are founded on deeply felt sociopolitical ideals, whose histories reach back to the revolutionary era of the later eighteenth century.

These different core values do not, to say it one last time, completely dictate the shape of the law on either side of the Atlantic. The contrast, like all such contrasts, is relative and not absolute. Moreover, there is no logical inconsistency in pursuing both forms of privacy protection: It is perfectly possible to advocate both privacy against the state and privacy against nonstate information gatherers-to argue that protecting privacy means both safeguarding the presentation of self and inhibiting the investigative and regulatory excesses of the state. Indeed, American advocates of privacy typically do just that, denouncing the threat to "privacy" indiscriminately, as coming both from the state and from the media. There is nothing illogical in this.

Nevertheless, the emphases and sensibilities of the law on either side of the Atlantic remain stubbornly different, whatever careful philosophical logic might allow or dictate. Privacy law is not the product of logic. But neither is it the product of "experience" or of supposed "felt necessities" that are shared in all modern societies. ${ }^{333}$ It is the product of local social anxieties and local ideals. In the United States those anxieties and ideals

332. See Roland G. Fryer, JR. \& STEVEN D. LevitT, The CAUSES AND CONSEquenCES of DisTinCTIVELY BlaCK NAMES 3-4 (Nat'l Bureau of Econ. Research, Working Paper No. 9938, 2003), http://papers.nber.org/papers/w9938.pdf.

333. Oliver Wendell Holmes, The COMMON LAW 1 (Mark DeWolfe Howe ed., Harvard Univ. Press 1963) (1880). 
focus principally on the police and other officials, and around the ambition "to secure the blessings of liberty," while on the Continent they focus on the ambition to guarantee everyone's position in society, to guarantee everyone's "honor." This was already true in 1791, in the French Revolution of Jérôme Pétion, and it remains true today.

This is not something we will ever understand if we do not get beyond the sort of shallow intuitionism that is the stuff of most of our privacy literature. Indeed, it is a basic error to try to explain or justify any aspect of the law by appealing to our unmediated intuitions about what seems evil or horrible. That kind of crude intuitionist approach has been rejected by most moral philosophers - most famously by John Rawls, who insisted that good moral reasoning is founded on a "reflective equilibrium" between intuitions and rational moral theory. ${ }^{334}$ Crude intuitionism is pretty much dead among moral philosophers, and it ought to be dead in the law too. Indeed, if anything, that sort of intuitionism is less acceptable in the law than it is in other realms of moral reasoning. In liberal Western societies, law is regarded as a weapon of last resort, to be drawn only when authentically fundamental values of society are at stake. This has a consequence that deserves to be stated over and over again: It is in the very nature of being a member of a liberal society that one must live with many things that seem horrible. If the sort of arguments mounted by privacy advocates were valid, many things indeed would be forbidden. Take only the example of adultery. One could easily offer an argument about adultery that took the same form as the arguments commonly offered in our privacy literature: Picture, one might say, your spouse having sex with someone else. Isn't it horrible? Horrible it may be, for most of us. But that does not decide the question of what the law should do about adultery. To decide that question, we must reflect on other, larger values-most particularly, on values of liberty.

The same is true of the law of privacy. We cannot simply start by asking ourselves whether privacy violations are intuitively horrible or nightmarish. The job is harder than that. We have to identify the fundamental values that are at stake in the "privacy" question as it is understood in a given society. The task is not to realize the true universal values of "privacy" in every society. The law puts more limits on us than that: The law will not work as law unless it seems to people to embody the basic commitments of their society. In practice, this means that the real choice, in the Atlantic world at least, is between social traditions strongly oriented toward liberty and social traditions strongly oriented toward dignity. This is a choice that goes well beyond the law of privacy: It is a choice that involves all the areas of law that touch, more or less nearly, on questions of dignity. 
We can respond to this choice by refusing to make it: We can opt for a world in which societies just do things differently. For example, we can declare that American gays can realistically expect only to have their liberty rights protected. The prospects for the kind of dignitary protections embodied in a law of gay marriage, we could say, are remote. After all, protecting people's dignity is quite alien to the American tradition. Or we can do what most moral philosophers want to do: We can reject the notion that different societies should have differing standards. But if we take that tack, we must face the fact that we will not succeed in changing either world unless we embark on a very large-scale revaluation of legal values.

In truth, there is little reason to suppose that Americans will be persuaded to think of their world of values in a European way any time soon; American law simply does not endorse the general norm of personal dignity found in Europe. Nor is there any greater hope that Europeans will embrace the American ideal; the law of Europe does not recognize many of the antistatist concerns that Americans seem to take for granted. Of course we are all free to plead for a different kind of law-in Europe or in the United States. But pleading for privacy as such is not the way to do it. There is no such thing as privacy as such. The battle, if it is to be fought, will have to be fought over more fundamental values than that. 
$* * *$

Imaged WinOnline $-\overline{113}$ Yale L.J. $12222003-2004$ Permission of Yale Law Journal 